\title{
Project
}

\section{An Assessment of Alternative Strategies for Increasing Access to Legal Services*}

Since the late 1930s, lawyers have argued that their services are not used to the fullest advantage by a large segment of the population. ${ }^{1}$ More recently, other concerned groups such as trade unions ${ }^{2}$ and consumer organizations ${ }^{3}$ also have become convinced that there is an underutilization of lawyers' services, and that it is important to increase access to such services. As a result, attempts have been made to develop alternatives to the traditional methods of providing legal services that to date have proved inadequate in meeting the legal needs of the public. Legal clinics have proliferated, ${ }^{4}$ prepaid legal services plans have been inaugurated on a wide scale, ${ }^{5}$ and the or-

* The authors wish to thank their advisor, Professor Stanton A. Wheeler, for his thoughtful comments, and Associate Dean Edward A. Dauer for his insights and support.

1. See, e.g., Smith, The Bar Association Law Office for Persons of Moderate Means (Designed for a Large City), 19 B.U. L. REv. 226, 226 (1939) [hereinafter cited as Bar Association Law Office]; Address by Solicitor General Robert H. Jackson, Junior Bar Conference of the American Bar Association (July 9, 1939), excerpts reprinted in Smith, Legal Service Offices for Persons of Moderate Means, 1949 WIs. L. REv. 416, 425 [hereinafter cited as Legal Services Offices].

2. The recent development of prepaid legal services plans owes much to the efforts of trade unions. The first modern attempts to organize a closed-panel prepaid plan was undertaken in 1957 by a restaurant workers union in Los Angeles whose members were largely Mexican immigrants with unmet legal needs concerning their installment purchases, debt arrangements, and marital situations. See Cedarquist, Lawyers at the Crossroads-Profession or Trade? 31 UNAuth. Prac. News 79, 83 (1965-66). Since that time, organized labor has expressed a growing interest in helping to broaden union members access to legal services. See Bernstein, Legal Services, the Bar and the Unions, 58 A.B.A.J. 472, 473 (1972); Resolution adopted by the 1972 UAW Constitutional Convention, reprinted in Recent Developments in Prepaid Legal Services Plans: Hearings Before the Subcomm. on Representation of Citizen Interests of the Senate Comm. on the Judiciary, 93d Cong., 2d Sess. 12-13 (1974) (statement of Leonard P. Woodcock) [hereinafter cited as Hearings].

3. See, e.g., National Conference on Prepaid Legal Services 409 (1972) (held in Washington, D.C., April 27-29, 1972) (report of Helen Nelson) (consumer representatives agree that consumers have great unmet need for legal services) [hereinafter cited as WAsHiNGTON Conference]; DeMent, Legal Services Dilemma: View from the Market, Trial, Aug. 1976, at 26 (consumer groups believe that significant segment of moderate income population lacks access to lawyers' services because of structure of profession).

4. See Slavin, Lawyers and Madison Avenue, BarRISTer, Summer 1979, at 47 (number of clinics expanded from 12 to more than 200 since 1977).

5. See Murphy, Prepaid Taking Root, Trial, June 1976, at 14-15 (describing growth of prepaid plans); Paying less for a lawyer, 44 Consumer REP. 522, 526 (estimating that 5 million families are covered by prepaid plans). 
ganized bar has attempted to revitalize its lawyer referral services. ${ }^{6}$ All of this has been done, however, without a complete understanding of why people do or do not use lawyers.

This Project examines factors said to affect utilization of legal services by analyzing the results of a national survey conducted between 1973 and 1974 by the Special Committee to Survey Legal Needs of the American Bar Association and the American Bar Foundation (ABA-ABF Survey). ${ }^{7}$ This analysis reveals that lawyer use depends principally upon three factors-the number of times a person has experienced a legal problem, whether a person owns real property, and whether a person has personal contacts with a lawyer. These findings are then used to evaluate the potential of several alternative legal delivery systems for increasing lawyer use. The Project concludes that closed-panel prepaid plans and legal clinics have the greatest potential for increasing lawyer use, though both may have only a limited impact.

\section{The Emerging Concern About Underutilization of Lawyers}

The legal profession has become increasingly concerned with the unmet legal needs of the public. Several types of alternative legal delivery systems have been devised to meet these needs. Unfortunately, knowledge of determinants of lawyer use is insufficiently developed to permit effective evaluation of these alternatives.

\section{A. A History of Increasing Concern}

Until the early 1930s discussion of the unmet need for legal services had focused primarily on the legal needs of the poor who were unable to obtain legal services on the customary fee-for-service basis. ${ }^{8}$

6. The primary focus of attempts to rejuvenate lawyer referral services has been the promulgation of a new Statement of Standards and Practices for a Lawyer Referral Service by the ABA. See Carlin, The Advancing State of the Art of Lawyer Referral Service, 30 B.AYLoR L. REv. 643, 648-51 (1978) (description of new standards).

7. The American Bar Foundation provided the raw data for this Project. The results of the survey are reported in B. Curran, The Legal Nefds of the Public (1977). The description of the data files and the index to their contents are set forth in $B$. Currin \& K. Rosich, Data Manual for the Survey of Legal Needs (1980).

The survey yielded an extensive data base that contains the most complete information on the incidence of legal problems and patterns of lawyer use ever compiled. Previous surveys of legal needs were either not based on representative samples or were restricted to one geographical area. See B. CuRRAN, supra, at 2-9. The ABA-ABF Survey is the first survey of legal needs using a national sample. $I d$. at 1 .

8. Perhaps the most important work in drawing attention to the unmet legal needs of the poor was Reginald Heber Smith's Justice and the Poor. Smith toured the nation's legal aid societies and courts, and concluded from this study that, "[t]he administration 
Legal aid societies were organized in many cities in an effort to meet this need, ${ }^{9}$ in part out of the belief that providing legal services to the poor was necessary to prevent violent social upheaval. ${ }^{10}$

In the 1930s, however, the view emerged that the segment of the population underserved by the legal profession was far broader, encompassing many persons of moderate means, as well as the poor. ${ }^{11}$ This view was doubtlessly enhanced by the serious economic hardships faced by the profession as a result of the Great Depression. ${ }^{12}$ During this period Dean Charles E. Clark of the Yale Law School and sociologist Emma Corstvet conducted the first survey of lawyer use. ${ }^{13}$ They concluded that " $[t]$ he lawyers' earnings are low, and there is a great deal of legal work undone which might become what the economists call 'effective demand' under other conditions." 14

This new interest in unmet legal needs stimulated calls for change in the traditional means of delivering legal services. Professor Karl

of American justice is not impartial, the rich and poor do not stand on an equality before the law, the traditional method of providing justice has operated to close the doors of the courts to the poor, and has caused a gross denial of justice in all parts of the country to millions of persons." R. SMITH, JUSTICE AND THE POOR 8 (1919). Publication of Smith's work sparked considerable controversy, and gave greater impetus to the legal aid movement in the United States. See E. Johnson, Justice and Reform: The Formative Years of the American legal Services Program 5-8 (1974).

9. At the turn of the century legal aid societies increased dramatically in number from the Deutscher Rechts-Schutz Verein founded in 1876 to protect poor German immigrants, to the 61 societies that in 1923 handled 150,000 cases. See J. AUERBACH, UNEQUAL JUSTICE 53-58 (1976). Legal aid did not enjoy comparable growth again until the 1950 s when the threat of a government financed national legal aid plan encouraged many state and local bar associations to support legal aid. See E. JoHnson, supra note 8 , at 9.

10. See J. AuERBACH, supra note 9, at 58 (fear of unrest accounted for growth of legal aid). Indeed, even as late as 1950 some supporters of legal aid were still touting it as a cost-effective way of avoiding the "powder keg" of "alien subversive doctrines." See Holtze, Legal Aid Societies Have Become a Vital Part of the Processes of Justice in Nation, 19 HENNEPIN LAW. 27, 27 (1950).

11. See Bradway, The Bar Association Law Office for Persons of Moderate Means (In a Non-Metropolitan Area), in The Economics of the Legal Profession 133, 134-35 (1938) (persons of moderate means in rural areas are in need of legal service, but do not obtain it); Bar Association Law Office, supra note 1, at 226 (huge class of persons of moderate means need legal help, but cannot find it); Address by Solicitor General Robert H. Jackson, supra note I (bar leaves persons who are neither well-to-do nor poor largely unserved).

12. See J. Auerbach, supra note 9, at 204 ("It took the Depression to provoke concern [for the unmet legal needs of lower- and middle-income people], less because people needed lawyers than because so many lawyers desperately needed clients."); Legal Services Offices, supra note 1, at 425 (bar's alarm at economic plight of members led to awareness of problem of unmet legal need).

13. The Clark and Corstvet study consisted of a survey of 412 residents and 61 small businesses in New Haven, Connecticut. The respondents came from wards primarily made up of lower and middle income groups. A separate survey was also made of 50 lawyers. The results of the survey appear in Clark \& Corstvet, The Lawyer and the Public: An A.A.L.S. Survey, 47 YALE L.J. 1272 (1938).

14. Id. at 1293. 
N. Llewellyn proposed that bar associations establish neighborhood law offices to provide limited advice and to refer clients to competent lawyers willing to perform standardized services for a sliding scale fee according to the client's income. ${ }^{15}$ Llewellyn further recommended that the availability of such lawyers be publicized through institutional advertising. ${ }^{16}$ Other commentators joined in the call for creation of neighborhood legal services offices specializing in providing lowcost legal services to persons of moderate means. ${ }^{17}$ Although a few offices were established along these lines, ${ }^{18}$ calls for reform remained largely unheeded by the organized bar. ${ }^{19}$

After World War II commentators continued to focus attention on the unmet need for legal services. ${ }^{20}$ During this period, a study conducted by Professor Earl L. Koos provided further empirical support for the proposition that large segments of the population were underserved by lawyers. ${ }^{21}$ This survey of working class and middle class families concluded that such families generally lacked the ser-

15. Llewellyn's proposals are set forth in Llewellyn, The Bar Specializes-With What Results? 167 ANNALs 177, 191-92 (1933) [hereinafter cited as The Bar Specializes], and Llewellyn, The Bar's Troubles, and Poultices-and Cures? 5 LAw \& Contemp. Prob. 104, 122-25 (1938) [hereinafter cited as The Bar's Troubles].

16. Llewellyn carefully limited his proposal to support for institutional advertising by the bar. He did not endorse advertising by individual lawyers. See The Bar's Troubles, supra note 15 , at 122 .

17. See, e.g., Bradway, Low-Cost Legal Service Bureaus, 17 N.C. L. REv. 101, 116.17 (1938); Bar Association Law Office, supra note I, at 229. The idea of low-cost neighborhood law offices received an enthusiastic response from young urban lawyers. J. AuERBACH, supra note 9 , at 207.

18. The National Lawyers Guild (Guild) was instrumental in implementing the idea of low-cost neighborhood law offices. See J. AUERBACH, supra note 9, at 207. In Chicago, Guild members established a centralized office to provide legal services to persons of moderate means. See Proposal for a Legal Service Bureau for the Metropolitan Area of Chicago, 1 Nar'L LAw. Gullo Q. 149 (1938) (describing proposed Chicago bureau). In Philadelphia, the Guild established a series of neighborhood legal services offices scattered throughout the city. See Abrahams, The Neighborhood Law Office Experiment, 9 U. ChI. L. Rev. 406, 411-12 (1942) [hereinafter cited as Law Office Experiment]. The Philadelphia experiment proved quite successful, with most offices becoming at least self-sustaining, and one office clearing more than $\$ 15,000$ in a year. See Abrahams, The Neighbarhood Law Office Plan, 1949 WIs. L. REv. 634, 639-40.

19. See J. AuERBACH, supra note 9, at 207; Law Office Experiment, supra note 18, at 407 .

20. One bar official asserted that "[t]he creation of adequate facilities which will assure competent legal advice and assistance to the millions of persons of moderate means has emerged as one of the greatest post-war problems confronting the organized bar." Legal Services Offices, supra note 1, at 416. Concern about unmet legal needs was stimulated by the fear that the failure to meet such needs might induce government, labor unions, or other institutions to encroach further on the bar's historical prerogatives in providing legal services. See Legal Services Policies, 32 A.B.A.J. 866 (1946).

21. Koos surveyed working-class and middle-class families in six cities in three geographic regions. Middle-class surveys were done by mail, while working-class respondents were surveyed through personal interviews. The results of the study appear in $\mathrm{E}$. Koos, The Family axd THE LAW (1952). 
vices of a lawyer in meeting problems best solved with a lawyer's assistance. ${ }^{22}$ In terms of actual reform, however, this era was less fruitful. In 1946, the American Bar Association (ABA) did endorse the use of lawyer referral services, ${ }^{23}$ but actively opposed other proposed innovations such as group legal services. ${ }^{24}$

During the last twenty years the delivery of legal services has changed dramatically with respect to the legal needs of the poor. In Gideon v. Wainwright, the United States Supreme Court held that an indigent person accused of a serious crime had a constitutional right to the assistance of counsel. ${ }^{25}$ With respect to civil matters, the federal government created the Office of Economic Opportunity (OEO) Legal Services Program to fund the development of a wide range of programs providing legal services to the poor on a national scale. ${ }^{20}$

Important strides also were made in implementing such innovations as prepaid legal services plans and legal advertising. Beginning in the 1960s, trade unions won a series of court battles that established their constitutional right to retain attorneys to provide personal legal services to their members. ${ }^{27}$ Under considerable pressure from the courts, Congress, and unions, the organized bar gradually revised its

22. Id. at 12 .

23. The first lawyer referral service office was opened in Los Angeles in 1937. B. Christensen, Lawyers for the People of Moderate Means 176 (1970). The service received the endorsement of the ABA House of Delegates in 1946. 71 A.B.A. REP. 109-10 (19.46).

24. The ABA's Canons of Professional Ethics had long proscribed the provision of group legal services and closed-panel prepaid plans. In 1928, Canon 35 was adopted, prohibiting an attorney from accepting employment from an organization if such employment included the rendering of legal services to the members of the organization in respect to their individual affairs. ABA Canons of Professional Ethics No. 35 (1928). Some forms of prepaid plans were permitted, but only if they specifically offered to pay for any attorney the member employed. See, e.g., In re Thibodeau, 295 Mass. 374, 378-79, 3 N.E.2d 749, 751 (1936).

When interest in group legal services and closed-panel prepaid plans increased in the late $1950 \mathrm{~s}$, bar association opposition to such schemes was renewed. See, e.g., Cedarquist, supra note 2, at 92-95; Committee on Group Legal Services, Group Legal Services, 34 J. ST. B. CAL. $318,339.43$ (1959).

25. 372 U.S. 335 (1963) (constitutional right to assistance of counsel in felony prosecutions). The subsequent decision in Argersinger v. Hamlin, 407 U.S. 25 (1972), extended the rule of Gideon to hold that no indigent defendant may be constitutionally deprived of liberty if he was denied the assistance of counsel.

26. See E. Johnson, supra note 8 , at $37-70$ (describing development of OEO Legal Services Program).

27. See United Transp. Union v. State Bar of Mich., 401 U.S. 576 (1971) (union plan designed to retain moderately priced attorneys in Federal Employers Liability Act actions held permissible); United Mine Workers v. Illinois State Bar Ass'n, 389 U.S. 217 (1967) (union's hiring of attorneys on salary basis to process members' workmen's compensation claims held permissible); Brotherhood of R.R. Trainmen v. Virginia ex rel. Va. State Bar, 377 U.S. 1 (1964) (union's recommendation of attorneys to its members in personal injury cases protected under First and Fourteenth Amendments). 
ethical restrictions on the growth of prepaid plans, ${ }^{28}$ at first to permit such plans only to the extent required by constitutional interpretations of the courts, ${ }^{29}$ and later to permit broader use of both closedand open-panel prepaid plans. ${ }^{30}$ The growth of prepaid plans was also encouraged by amendments to the Taft-Hartley Act that permitted unions to bargain collectively for prepaid legal services as a fringe benefit of employment, ${ }^{31}$ and by amendments to the Internal Revenue Code that afforded such benefits favorable tax treatment. ${ }^{32}$

Further innovations in the delivery of legal services resulted from the Supreme Court's landmark decision in Bates v. State Bar of Arizona, ${ }^{33}$ which struck down a state's blanket ban on attorney advertising as an unconstitutional abridgment of commercial speech. The Bates decision led directly to a proliferation of low-cost legal clinics that provide standardized legal services. ${ }^{34}$

At the same time that innovations in the delivery of legal services were finally achieving actual implementation after years of academic discussion, concern about the legal needs of the public led to the most ambitious study of legal needs yet undertaken. In 1971, an ABA House of Delegates resolution directed that a nationwide survey be conducted "to ascertain the extent to which the public recognizes the need for and uses legal services." ${ }^{35}$ The survey found that respondents

28. When the ABA sought to retain ethical restrictions on closed-panel prepaid plans, groups operating prepaid plans threatened to sue the ABA for violation of the antitrust laws and infringement of First and Fourteenth Amendment rights. See L. DEITCH \& D. Weinstein, Prepaid Legal Services 22 (1976). Hearings were held by the Senate Judiciary Subcommittee on Representation of Citizen Interests, during which several witnesses attacked the bar's position. See Hearings, supra note 2, at 5-7, 19-21, 98 (testimony of Stephen Schlossberg, Robert J. Connerton, and Bruce B. Wilson).

29. The new Code of Professional Responsibility adopted in 1969 permitted nonprofit organizations to recommend, furnish, or pay for legal services to their members, but only to the extent that controlling constitutional interpretations required the allowance of such activitics. ABA Code of Professional Responsibility, Disciplinary Rule 2-103(D)(5) (1969).

30. In 1975, the ABA amended the Code of Professional Responsibility to permit operation of both closed-panel and open-panel prepaid plans, provided that seven relatively non-restrictive requirements are met. See ABA CODE of Professional Responsibilitx, Disciplin.iRY Rule 2-108(D)(5) (1976).

31. Labor Management Relations Act Amendments of 1973, Pub. L. No. 93-95, 87 Stat. 314 (codified at 29 U.S.C. $\$ 186$ (c) (1976)).

32. Tax Reform Act of 1976, Pub. L. No. 94-455, $\S 2134(\mathrm{~b}),(e), 90$ Stat. 1520 (codified at I.R.C. $\$ \$ 120,501(\mathrm{c})(20)$ ). Under the new Internal Revenue Code provisions an emplojer may deduct contributions made to a prepaid plan, and neither the employer's contribution nor services received by employees under the plan are taxed as income to the employees. I.R.C. $\$ \$ 120(\mathrm{a})(\mathrm{l}),(2), 501(\mathrm{c})(20)$.

33. 433 U.S. 350 (1977).

34. See Bodine, Proliferation of Legal Clinics Continues; 550 More Were Born in Last 10 Months, N.AT'L L.J., Dec. 31, 1979, at 5; Slavin, supra note 4, at 47.

35. 96 A.B.A. REP. 143-44 (1971). 
encountered an average of five selected situations presenting potential legal problems, ${ }^{36}$ but that one-third had never used a lawyer and another third had used a lawyer only once. ${ }^{37}$ This seeming incongruity between incidence of legal problems and actual lawyer use led many commentators to conclude that a large unmet legal need existed among the general public. ${ }^{38}$

\section{B. Three Alternative Legal Delivery Systems}

During the past fifteen years, three alternative legal delivery systems-lawyer referral services (LRSs), prepaid legal service plans, and legal clinics-have grown in part as a response to increasing concern about unmet legal need. ${ }^{39}$

\section{Lawyer Referral Services}

Lawyer referral services confer with those wishing to consult an attorney. ABA standards require the LRS person "screening" the request for an attorney to be an attorney $y^{40}$ but many LRS offices do not conform to the standards. In addition, not all LRSs provide for a screening interview. ${ }^{41}$ The capacity of an LRS to conduct an effective screening interview is limited by the number of staff lawyers employed by the LRS. ${ }^{42}$ After this initial interview, the LRS refers the caller to an attorney on its list of participating lawyers. ${ }^{43}$ The potential

36. B. Curran, supra note 7, at 100 . The precise mean number of legal problems per respondent was 4.8. Nearly a third of the sample had encountered six or more legal problems during their lives. Id. at 100.

37. Id. at 185-86, 190.

38. See, e.g., Carlin, supra note 6, at 643-45; Zander, How to Explain the Unmet Need for Legal Services, 64 A.B.A.J. 1676 (1978).

39. Other alternatives have been suggested, including expanded use of lawyer lists and lawyer directories, see Christensen, Toward Improved Legal Services Delivery: A Look at Four Mechanisms, 1979 AM. B. Foundation Research J. 277, 285-89, and private referral services, see ABA Consortium on Legal Services and the Public, Legal SERvices for the Average Citizen 17-18 (1977) [hereinafter cited as Average Citizen]. These alternatives have yet to receive widespread attention or be implemented on a large scale, and therefore are not analyzed in this Project.

40. Carlin, supra note 6, at 648-51. These standards of the ABA Lawyer Referral Standing Committee are hortatory only; the Committee has no control over local referral services. $I d$. at 648 .

41. See B. ChRISTENSEN, supra note 23 , at 174 .

42. See Carlin, supra note 6 , at 651 (in 1975 only $12 \%$ of LRSs reported having staff attorney).

43. Some referral services give the client the names of three attorneys from which to choose. See Christensen, supra note 39, at 289. Others have panels of attorneys who specialize in a particular field of law. Licensed attorneys usually join an LRS list merely by volunteering, without undergoing extensive screening. See B. Christensen, supra note 23, at 178. But see Murphy, Lawyer Reference Plan-The Complete Delivery System for Legal Services, in Legal Deliverx Systems: Available Alternatives 247, 255-57 (1977) (Chicago Bar Association uses extensive screening for LRS panel applicants). 
client then makes an appointment to meet with the attorney at a nominal fee, usually between fifteen and twenty-five dollars. ${ }^{44}$ After the initial consultation, the lawyer and client are free to establish any fee arrangement that is mutually agreeable. ${ }^{45}$ Lawyer referral services, generally sponsored by local bar associations, have constituted the organized bar's principal effort to increase access io lawyers during the last forty years. ${ }^{40}$

\section{Prepaid Legal Services Plans}

Prepaid legal services plans, a more recent phenomenon, ${ }^{47}$ seek to spread the risk of legal difficulty and the cost of legal services over a group of persons. ${ }^{48}$ Prepaid plans, though appearing in many forms, ${ }^{49}$ can be generally categorized as either open- or closed-panel arrangements. ${ }^{50}$

Open-panel prepaid legal insurance plans insure members for fixed amounts of legal services during specified time periods. ${ }^{51}$ Open-panel

44. Berg, Lawyer Referral Services, in ABA, LEg.AL SERvices For the Middle Class I, $3(1979)$.

45. Id. About one-half of all referrals do not go beyond the initial consultation stage. Haydock, Lawyer Referral in New York, in Legal Delivery Systems: Available AlterNATIVES 279, 282 (1977).

46. See B. ChRISTENSEN, supra note 23 , at 173 , 176. In 1978, there were 294 referral services, and the 188 services that responded to a survey reported receiving 919,464 requests for assistance and making 610,928 referrals. Christensen, supra note 39 , at 286 n.33.

47. The first prepaid legal services plan actually appeared as early as 1889 . Delk, The Advent of Prepaid Legal Seruices in North Carolina, 13 WAKE Foresr L. Rev. 271, 274 (1977). The North Carolina and similar plans, however, did not succeed because of opposition from the organized bar. See L. DeITCH \& D. WeInstein, supra note 28, at 13-17; Delk, supra, at 274-75. More recently, under pressure from the Supreme Court, Congress, and trade unions, the ABA decided to liberalize its ethical restrictions on participation in prepaid plans. See L. Deitch \& D. Weinsteis, supra note 28, at 17-23.

48. See W. Pfennigstorf, Legal Expense Insurance 2 (1975). There are currently more than 2,000 prepaid plans operating nationally, see DeMent, Prepaid Legal Services: A Review of Theory and Practice, 30 BAYLOR L. Rev. 625, 635 (1978), covering more than five million families, see Paying less for a lawyer, supra note 5, at 526.

49. For discussions of the variety of prepaid legal services plans, see Broadman \& Ohman, New Directions in Legal Services: Group and Prepaid Legal Services Plans in New York, in Legal Delivery Systems: Available Alternatives 107, 117.43 (1977); Ohman, An Overview of Five Legal Service Plans, 2 New Directions in Legal Services 5 (1977); Comment, Prepaid Legal Services: Obstacles Hampering Its Growth and Development, 47 ForDHAM L. REv. 841, 843-57 (1979).

50. Some plans may combine elements of the open- and closed-panel arrangements. See Goodman, Development of Prepaid Legal Services Plans, in ABA, Legal Services For THE Midde Class 15,19 (1979).

51. Open-panel plans exhibit a variety of benefits and coverage. Some plans limit coverage to a percentage of fees charged for specified types of services. See, e.g., Broadman \& Ohman, supra note 49, at 136-37 (benefit schedule for New York County Legal Services Corporation Prepaid Legal Services Plan). Others state coverage in terms of a certain number of hours of legal work per year. See, e.g., Ellis, An Overview of Prepaid Legal Services-Open Panel, in Legal Delivery Systems: Available Alternatives 145, 153-54 (1977). 
plans have been sponsored primarily by bar associations but also by general third-party insurers ${ }^{52}$ and employers ${ }^{53}$ or employee organizations. ${ }^{54}$ With an open-panel plan, the insured selects his own attorney and the insurer pays the attorney directly for his services. The bar has consistently supported the open-panel concept rather than closed panels, in part, because of the importance of choice in selecting an attorney. ${ }^{55}$ However, the bar's opposition to closed panels may also have been motivated by considerations of self-interest. ${ }^{56}$

Closed-panel plans are sponsored by groups that retain a law firm or hire their own legal staffs to deal with many legal problems common to their covered members. Any group can sponsor a prepaid plan. Thus far plans have been sponsored by trade unions, ${ }^{57}$ teachers' associations, ${ }^{58}$ consumer cooperatives, ${ }^{59}$ and student organizations and schools. ${ }^{60}$ Reformers have preferred closed-panel plans over open-panel plans. ${ }^{\circ 1}$ Closed-panel plans typically cover members only when they use the services of the retained staff or law firm. Although the member's freedom of choice is thus somewhat restricted, commentators have identified several advantages of closed panels, among them better quality control, lower cost, and greater lawyer contact. ${ }^{.2}$

Both closed- and open-panel plans enable the insured to budget

52. WAShington Conference, supra note 3, at 118 (remarks of William DeBuse) (prepaid plan open to general public); DeMent, supra note 48 , at $636-37$ (insurance companies initially deterred from offering prepaid due to perceived low potential for profit but now showing greater interest); Murphy, supra note 5, at 15 (two insurance companies offering open-panel prepaid but limited to discrete groups).

53. Open-panel plans often result from the joint efforts of employer and employee groups through collective bargaining agreements. More than 60 such arrangements existed in 1976. Usually, the employer contributes between 4 and 15 cents per worker hour to a joint fund for legal expenses while workers contribute between 3 and 10 cents per hour to the fund. Murphy, supra note 5, at 14-15. Employers appear not to have sponsored prepaid plans on their own. L. Deirca \& D. WeINSTEIN, supra note 28, at 36-37.

54. The Shreveport plan, begun in 1971 and considered by some the "first plan in the United States that offered substantial coverage of personal legal problems to the working man," was an open-panel plan covering union members. Murphy, supra note 5 , at 14. See also F. Marks, The Shreveport Plan (1974).

55. See Keating, What You Always Wanted to Know About Prepaid Legal Services, 57 Mich. Sr. B.J. 18, 21-22 (1978).

56. See Hermann, Prepaid Legal Services Coming of Age, 48 N.Y. ST. B.J. 438, 442-43 (1976). Bar discussion of prepaid plans has frequently involved a mix of public-interest and private-gain considerations. See, e.g., Keating, supra note 55, at 25 (both public's interest and lawyers' interests should be considered when discussing prepaid plans).

57. See Ohman, supra note 49 , at 5 .

58. See Ohman, NEA Eyes Future of Prepaid and Group, 3 New Directions IN LEgaL SERVICES 20, 20 (1978).

59. See Fifth National Conference on Prepaid Legal Services 89.90 (1975) (held in New Orleans, La., May 8-10, 1975) (remarks of Harriet Thayer).

60. See Adams, Student Legal Service Plans: A Fast-Growing Service on College Campuses, 4 New Directions in Legal Services 3, 3 (1979).

61. See DeMent, supra note 48 , at 633-34.

62. See L. Deitch \& D. Weinstein, supra note 28 , at 41 ; Ellis, supra note 51 , at 148 (better cost and quality control); pp. 151-52 infra (greater lawyer contact and lower costs). 
legal expenses and spread the risk of incurring major legal expenses across a large number of people. ${ }^{63}$ Another advantage common to both closed-and open-panel plans is the lower cost of fee collection. These savings can be passed on to consumers, decreasing the overall cost of providing legal services. ${ }^{64}$

\section{Legal Clinics}

The third popular form of alternative legal services delivery, legal clinics, ${ }^{65}$ are law firms designed to serve clients with routine legal problems. Routine legal problems are those that usually can be handled in the same way each time, such as uncontested divorces, simple wills, nonbusiness bankruptcies, and residential property transactions. ${ }^{60}$ Many clinics specialize only in routine services. ${ }^{\circ 7}$ Some, however, perform such nonroutine services as personal injury litigation. ${ }^{68}$ Legal clinics, on average, charge lower fees than traditional law firms ${ }^{69}$ and rely on extensive advertising to attract the large clientele such operations require. ${ }^{70}$

\section{Proposed Determinants of Lawyer Use}

There exists no well-developed theory of lawyer use. ${ }^{71}$ In reviewing the literature of legal need and legal service delivery methods, one

63. See B. Christensen, supra note 23 , at 65-66.

64. See L. Deitch \& D. Weinstein, supra note 28 , at 74.

65. Barlow Christensen rekindled modern interest in the legal clinic concept first developed by Llewellyn. See B. Christensen, supra note 23, at 205. The first law firm to use the name legal clinic was The Legal Clinic of Jacoby \& Meyers in Los Angeles, established in 1972. Maron, Legal Clinics: A Status Report, in Legal Delivery Systems: Avillable Alternatives 239, 241 (1977). Although there were only 12 clinics in 1977 prior to the decision in Bates v. State Bar of Ariz., 433 U.S. 350 (1977) (striking down flat ban on attorney advertising), there are now an estimated 700 clinics, including numerous branches of the same clinic, see Bodine, supra note 34 , at 5 .

66. See Muris \& McChesney, Advertising and the Price and Quality of Legal Services: The Case for Clinics, 1979 Am. B. Foundation Research J. 179, 192.

67. See Draznin, Legal Clinics: Illegitimate Children of Permissive Advertising Rules, in ABA, Legal Services for the Middle Class 28-29 (1979).

68. See, e.g., Meyers, Legal Clinics: Their Theory and How They Work, 52 L.A.B.J. 106, 107 (1976) (Jacoby \& Meyers' fee schedule for personal injury cases). But see Stark, Jacoby is Meyers Charges More Than Wall Street, AM. LAw., Aug. 1979, at 1, col. I-2 (ficld study indicating that clinics may not deal effectively with nonroutine problems). 69. See D. Maron, Legal Clinics: Analysis and Survey 8 (2d ed. 1977); Muris \& McChesney, supra note 66, at 195-96.

70. See Meyers, supra note 68, at 107; Muris \& McChesney, supra note 66, at 183 .

71. One author notes that little is known about the process of obtaining a lawyer, less than what is known about the process of using medical services. "A number of factors influence how clients come to perceive problems as amenable to legal assistance. These are certain psychological, cultural, and social attributes whose operation in law is less well understood than it is in medicine." Ladinsky, The Traffic in Legal Services: Lawyer-Seeking Behavior and the Channeling of Clients, 11 LAw \& Soc'Y REv. 207, 207 (1976). 
commentator observed that a "striking feature" of the area is "the sparseness of the literature directly on point."72 Commentators who discuss the subject simply point out particular factors that arguably affect whether a person uses an attorney in a given situation. ${ }^{73}$ All too often such statements are supported by personal observations or accepted wisdom but lack a thorough theoretical basis. ${ }^{74}$ Only rarely does empirical evidence support the pronouncement of conventional wisdom. ${ }^{\mathbf{7}}$

Despite the lack of a well-developed theory, however, the literature does include seven factors that, according to different commentators, significantly affect a person's decision to use a lawyer. Each explanatory factor rests on its own assumptions. An adequate examination of use of lawyers' services must test each of these factors.

Some commentators have argued that disposable income determines use of legal services-that is, that persons with higher income tend to use more legal services. ${ }^{76}$ This explanation assumes that conven-

72. Lempert, Mobilizing Private Law: An Introductory Essay, 11 LAw \& Soc'y Rev. 173, 176 (1976) (discussing Marks, Some Research Perspectives for Looking at Legal Need and Legal Delivery Systems: Old Forms or New? 11 LAw \& Soc'x REv. 191 (1976)).

73. See, e.g., Sklodowski \& Rathe, Aid For The Middle Class: Deduction of Legal Expenses, CASE \& Comment, Mar.-Apr. 1980, at 40. The article primarily advocates a personal income tax deduction for legal expenses modeled after the existing medical expense deduction. Before advancing this proposal, the authors note, without supporting citations, that "[t]here are two important reasons why so many people fail to make use of an attorney. The first reason is simple ignorance ... . Secondly, the cost of legal assistance deters many from the use of an attorney. Whether or not it is based on fact, there is a widespread belief that legal help is always expensive." $I d$. at 40 .

74. The history of concern discussed above largely rested on intuition. One author's 1968 observation remains accurate:

There is no direct evidence that the middle class needs more legal service than

it is presently getting. Citations can be collected stating that there is a need, but the sources cite each other, not broad, careful empirical research. Indubitably, many people think there is an unfilled need, and a persuasive case can perhaps be developed from reflecting about the growth and problems of modern society.

Stolz, Insurance for Legal Services: A Preliminary Study of Feasibility, 35 U. CHI. L. Rev. 417,419 (1968) (footnotes omitted).

75. One author concludes that " $[\mathrm{t}]$ here has been little empirical investigation of ... the ways in which individuals are linked to providers of legal services. . ." Lempert, supra note 72, at 176 . Another notes that evaluation of the suggested factors affecting lawyer use "will have to await more empirical research in the delivery of legal services." Ladinsky, supra note 71, at 209.

Some empirical studies have been based on such small localized samples that they more closely resemble intuitive essays. See, e.g., Frierson, Legal Advertising-Can It Be a Life Preserver for the Profession? BARRIster, Winter 1975, at 6 (author, on basis of questions administered to 40 residents in one locality, found that public grossly overestimates cost of routine legal services). The majority opinion in Bates $v$. State Bar of Ariz., 433 U.S. 350, 378 (1977), cited the Frierson study with approval. An exception to the usual lack of empirical research is Mayhew \& Reiss, The Social Organization of Legal Contacts, 34 AM. Soc. Rev. 309 (1969), which reports extensive survey data results.

76. See, e.g., Cahn \& Cahn, The War on Poverly: $A$ Civilian Perspective, 73 YaLE L.J. 1317, 1334-40 (1964); Carlin, Howard, \& Messinger, Civil Justice and the Poor, 1 LAw \& Soc'y REv. 9, 26, 55 (1966). 
tional theories of market behavior apply to the purchase of legal services. ${ }^{i 7}$ Although some members of the bar, principally those opposed to advertising by attorneys, ${ }^{78}$ have argued that lawyers and clients do not behave as producers and consumers do in a normal market exchange, ${ }^{70}$ many scholars have disputed this view. ${ }^{80}$ Though regulated, restricted in its entry, and less understood by the consumer than other markets, the legal services market nevertheless involves an exchange of compensation for services. There exist many suppliers of such services. ${ }^{81}$ It seems reasonable that consumers will choose among these suppliers based on their needs, resources, and information despite some systemic barriers to completely free consumer choice. ${ }^{82}$

There are two versions of the disposable income hypothesis. The first posits that income correlates in a linear fashion with the purchase of legal services. ${ }^{83}$ According to this view, the very poor make least use of lawyers because they lack available funds to retain an attorney, even in situations with serious legal implications. ${ }^{84}$ The very rich, by contrast, retain attorneys in situations presenting only the barest possibility of legal consequence because they possess ample funds for such expenses. ${ }^{85}$

The second version of the income hypothesis posits that, because

77. See R. Dorfman, Prices and Markets 78-80 (1967).

78. See, e.g., Bates v. State Bar of Ariz., 433 U.S. 350, 368-78 (1977) (discussing bar association arguments that advertising would increase cost of legal services but not use of lawyers).

79. See Birnbaum, Legal Services Dilemma: View from the Bar, Trial, Aug. 1976, at 27 (attorneys' "dedication to strict and honest self-regulation" distinguishes them from businessmen); Jeffers, Institute on Advertising Within the Legal Profession-Con, 29 OKLA. L. REv. 620, 620 (1976) (lawyer's "prime duty is a public duty").

80. See T. Parsons, Essays in Sociological Theory 34 (1954); The Bar Specializes, supra note 15, at 178 (corporate law practice operates much like any other business).

81. A. Nichols, The Pricing of Physicians' and Lawyers' Services 6-7, 9, 57, 62-63 (1975) (unpublished Ph.D. dissertation in Yale Law School Library) (discussing wide geographic dispersion and substantial income variation among more than 355,000 licensed attorneys in United States in 1970). This situation has existed for some time. Q. JoHnstone \& D. Hopson, LAwYers AND Their WORK 16 (1967) (296,000 attorneys-one lawyer for every 637 persons-in United States in 1963).

82. See generally E. Chamberlin, The Theory of Monopolistic Competition (8th ed. 1962); J. Robinson, The Economics of Imperfect Competition (2d ed. 1969).

83. See, e.g., B. Christensen, supra note 23, at $40-41$ (ability to afford legal services important factor in decision to use a lawyer).

84. Although use of the contingency fee minimizes this problem for low income persons seeking recompense for personal injury, such difficulties comprise a relatively small portion of public legal need. B. CuRran, supra note 7, at 103-04. Other causes of action allowing use of the contingency fee, such as a plaintiff's antitrust action, affect poor persons only infrequently.

85. At this point, the first income hypothesis begins to merge with the property ownership explanation of lawyer use. The latter view holds that property owners encounter more legal problems, not because of their greater wealth, but because owning property involves them in activities that result in greater interaction with the legal system. 
the poor have access to free legal aid programs, lowest lawyer use occurs among middle income groups ineligible for legal aid but lacking disposable income with which to retain private attorneys. ${ }^{80}$

Initially, the former version of the disposable income explanation dominated discussion of the use of lawyers' services. Expanded legal aid programs resulted, in part, from adherence to this view of the unmet legal need..$^{87}$ The very success of these programs ${ }^{88}$ helped foster the second version of the hypothesis. ${ }^{89}$ Today's interest in legal clinics

86. See, e.g., B. Christensen, supra note 23, at 5 n.4 (although extensive documantation does not exist, it appears that legal needs of middle income persons are underserved); Meserve, Our Forgotten Client: The Average American, 57 A.B.A.J. 1092, 1093 (1971) (bar is not providing adequate services to middle class individuals). The middle income "gap" is also seen as a major cause of unmet legal need in England. I RoyaL Commission on Legal Services, Final Report 44 (1979) ("certain classes of people who need the assistance of lawyers but cannot afford it are not eligible for financial assistance....")

87. The 1967 Amendments to the Economic Opportunity Act of 1964, 42 U.S.C. $\$ 2809$ (a)(3) (1976), authorized the Director of the Office of Economic Opportunity to establish a legal services program "to provide legal services to persons unable to afford the services of a private attorney." See H.R. REP. No. 866, 90th Cong., lst Sess. 24-25, reprinted in [1967] U.S. Code Cong. \& AD. News 2428, 2477. Legislative history accompanying subsequent amendments to the Act in 1969, 42 U.S.C. $\$ \$ 2809(\mathrm{a})(1), 2809(\mathrm{a})(3)(1976)$, and 1972 , 42 U.S.C. $\$ 2809$ (1976), as well as the creation in 1974 of the independent Legal Services Corporation (LSC), 42 U.S.C. $\$ 2996$ (1976), replacing the OEO legal service program, continued to emphasize the detrimental effect of poverty on lawyer use. See S. REP. No. 453, 91st Cong., lst Sess. 19-22, reprinted in [1969] U.S. Code CoNG. \& AD. News 2628, 2647; H.R. ReP. No. 815, 92d Cong., 2d Sess. 5, reprinted in [1972] U.S. Code CoNG. \& AD. News 3224,3228 .

88. In 1972, the Director of OEO stated that the legal services program helped "millions of poor Americans" gain access "to legal redress that once was denied them by their lack of means." H.R. REP. No. 815, 92d Cong., 1st Sess. 28, reprinted in [1972] U.S. CODE CONG. \& AD. NEws 3224, 3250 (discussing hearing testimony of OEO Director Frank Carlucci). In 1968, the OEO legal services program supported 265 local legal aid programs involving 1400 attorneys. S. REP. No. 453, 91st Cong., 1st Sess. 19-20, reprinted in [1969] U.S. Code Cong. \& AD. News 2628, 2648. In 1976, the ISC aided 300 local programs involving nearly 3,000 full-time attorneys and 1,200 legal assistants. H.R. REP. No. 310, 95th Cong., Ist Sess. 3, reprinted in [1977] U.S. Code Cong. \& Ab. News 4503, 4505.

89. Most commentators advancing the poverty version of the income explanation of lawyer use wrote prior to 1970. See, e.g., Carlin, Howard, \& Messinger, supra note 76, at 26-28; Project, The Legal Problems of the Rural Poor, 1969 DukE L.J. 495, 593-95. Since 1970 , the bulk of writing addressing the income factor has centered on the resources gap of the middle class. See, e.g., Royal Commission on Legal Services, supra note 86, at 44; Meserve, supra note 86 , at 1092.

Some commentators have attacked the poverty theory of income-based unmet need as a self-fulfilling prophecy. See, e.g., M. Zander, Legal Services For the Comimunity 288 (1978) ("One reason for this conclusion [that income and lawyer use correlate] is that studies have focused on the problems of the poor rather than investigating the problcm in the whole population.") Zander claims that "[t]he theory that poverty is the chief cause of the unmet need collapses in the face of the empirical evidence ...."Id. No such attack on this theory occurred during the 1960s. Many attorneys, however, see legal aid services as meeting only a portion of the legal needs of low income persons. See F. MARhs, The Legal Needs of the Poor: A Critical Analysis 1, 9 (1971) (poor should be allowed to define services available to them through OEO Legal Services Program); Carlin, Howard, \& Messinger, supra note 76, at 55-56 (restrictions on legal aid activities and personnel and financial shortages prevent complete free coverage of legal needs of poor).

Furthermore, the middle class gap version of the income hypothesis is not new, see, 
and prepaid plans for wage earners reflects both this shift of views as well as the relative decline of adherence to income theory in the face of alternative explanations.90

One such alternative, related to the income hypothesis, suggests that consumers are deterred from using legal services because they do not consider such services to be worth the cost. This explanation, like the income theory of underutilization, assumes that conventional theories of market behavior apply to the purchase of legal services. ${ }^{91}$ Should this explanation of the unmet need prove correct, increased lawyer use would await the development of a variety of less expensive means of delivering legal services appropriate to different income strata. The most widely used method of service delivery would be one that best fits the demand curve of the largest number of people.

A third analysis of lawyer use holds that some consumers can not identify the legal implications of a situation. Consequently, they do not realize the value of consulting an attorney and therefore do not use a lawyer. ${ }^{92}$ One commentator describes this as the "legal incompetence" theory. ${ }^{93}$ It posits that persons would use lawyers more often if they were more aware of the potential legal implications of situa-

e.g., Stason, Leary, Mcintyre, \& KJellenberg, American Bar Foundation Research Memrorandum Series No. 9: Supplementary Miemorandum on Prepaid Legal Expense INSURANCE I (1960) ("Legal aid organizations have substantially answered the need for the indigent .... However, certain elements of the Bar have recognized that many persons of moderate means in this country are still without adequate legal services for a variety of reasons."), but appears to enjoy a larger following now than in the past.

90. Income factors affecting legal needs have been discussed by the profession since the advent of legal aid during the 1880s. See J. AunRBach, supra note 9, at 53-56. However, other explanations of lawyer use arose during the 1960s and 1970s. See pp. 135-38 \& notes 91-106 infra.

91. See, e.g., R. Dorfman, supra note 77, at 84-86. Examples of this approach can be found in Paying less for a lawyer, supra note 5, at 523; Stein, Legal Services and the Middle Class, 53 N.D. L. REv. 573, 580 (1977) (consumers believe legal services not worth the cost). The English also see this as an impediment to lawyer use. Royal CoMMISSION ON LEGAL SERvices, supra note 86, at 45 ("There may be reluctance to consult a lawyer for fear of what is involved, in particular the cost.")

92. See, e.g., Missouri Bar, Missouri Bar Prentice hall Survey: A Motivational Study of Public Attitudes and Law Office Management 136 (1963); Royal Commission ON LEGAL SERviCES, supra note 86, at 45; Carlin \& Howard, Legal Representation and Class Justice, 12 U.C.L.A. L. REv. 381, $423-24$ (1965); Stein, supra note 91, at 580; Stolz, supra note 74 , at $419-20$.

93. M. ZANDER, supra note 89 , at 288; Zander, supra note 38, at 1676-77. Zander rejects the legal incompetence theory. Reviewing the ABA-ABF Survey, a similar study in Australia, and a study of allegedly legally competent Wisconsin businessmen, see Macauley, Non-contractual Relations in Business: A Preliminary Study, 28 AM. Soc. Rev. 61 (1963), he concludes that "the kind of problem seems to cause much greater differences in lawyer use than the kind of potential client." M. ZANDER, supra note 89, at 289. He reasons that legal incompetence varies according to the problem and is evenly distributed across economic, social, and occupational groups. 
tions and argues that increased lawyer use would be fostered by a delivery system that increased public legal awareness. ${ }^{94}$

Individual attitudes toward lawyers and the legal system constitute a fourth factor said to affect lawyer use. According to this hypothesis, persons with more positive attitudes are more likely to use lawyers. ${ }^{95}$ Central to this view is the belief that many persons regard attorneys in traditional practice as aloof, uncaring, and inclined to complicate rather than resolve a person's problems. ${ }^{96}$

Attitude toward the legal system also includes a person's predisposition to use legal services. For example, although the ABA-ABF Survey respondents generally gave attorneys a positive evaluation, fortythree percent agreed that "[a] person should not call upon a lawyer until he has exhausted every other possible way of solving his problem." 97 Insofar as attitude determines lawyer use, the alternative service delivery system that improves the public image of the profession will also increase use of attorneys by the public.

A fifth hypothesis-that experience determines lawyer use-is derived from the common sense notion that the greater the number of situations a person experiences in which a lawyer could be helpful, the more likely he is to consult a lawyer. If, as some contend, ${ }^{08}$ lawyer use varies significantly according to type of legal problem, personal experience may constitute the most important factor affecting lawyer use. To the extent that this explanation alone proves true, service delivery methods can do little to increase public lawyer use.

A sixth explanation suggests that ownership of real property intro-

94. One Denver study found that attorneys in neighborhood law offices often perceived more and more serious legal problems in the situations brought to them than did their clients. Sykes, Legal Needs of the Poor in the City of Denver, 4 Law \& Soc. REv. 255, 262-63 (1969).

95. See, e.g., F. Marks, supra note 54, at 39; Missouri Bar, supra note 92, at 136.

96. Although attorneys enjoy generally good community prestige, they also are considered more academic and less pragmatically helpful than accountants, bankers, and real estate agents. Q. JoHNSTONE \& D. Hopson, supra note 81, at 69 "Despite their relatively high prestige ranking, lawyers come in for considerable public criticism.") One British scholar theorizes that "[g]oing to a solicitor is probably regarded by most of those who contemplate it as being about equal in attraction to seeing the dentist-it may be necessary, but it is hardly likely to be a pleasant experience." M. ZANDER, supra note 89 , at 293 .

Seven years after Johnstone and Hopson wrote, the Watergate scandal and many of its principal villains, attorneys, dominated national news. Most observers believe Watergate undermined the prestige of lawyers. See, e.g., J. AuERBAch, supra note 9, at 301, 302 ("Watergate was the most severe jolt [of the post-War era] to the integrity of legal authority.... The response of legal institutions was as destructive to confidence in the legal order as was the criminal activity itself.")

97. B. Curran, supra note 7, at 254-55.

98. See note 93 supra; B. CURRAN, supra note 7, at 160. 
duces one into a network of social and economic connections that lead to use of a lawyer. ${ }^{99}$ Property ownership indicates a high probability that a person is familiar with lawyers, has experienced a number of situations in which a lawyer might be helpful, and has a relatively high income. ${ }^{100}$ This hypothesis is, to date, the only one well-supported by empirical data. Sociologists Leon Mayhew and Albert Reiss surveyed 780 persons in the Detroit area and found property ownership closely correlated with lawyer use. ${ }^{101}$ Like the experience explanation, the property hypothesis, if true, suggests that delivery methods will have limited impact on public lawyer use. Nevertheless, delivery methods that touch upon a component of the property explanation, such as personal contacts with the legal system, may increase lawyer use.

In fact, a seventh explanation of lawyer use emphasizes the importance of personal contact with those who can knowledgeably and authoritatively suggest use of a lawyer. ${ }^{102}$ According to this hypothesis, the presence of informed intermediaries forms the crucial link in the chain of lawyer use: those having such contact are more likely to use an attorney. If this notion explains lawyer use, delivery methods creating or increasing such personal contacts will increase public use of attorneys.

The foremost proponent of the informed intermediaries theory speaks of "lay" intermediaries. ${ }^{103}$ However, the informed middleman urging lawyer use could be an attorney as well as a doctor, policeman, teacher, or employer. Most commentators appear to agree and, when discussing the role of personal contact in the decision to use an at-

99. See Mayhew \& Reiss, supra note 75 , at 313 (respective orientations of legal profession toward business and property, and social organization of business and property toward law results in greater lawyer use by persons owning real property than by nonowners).

100. Id. at 312-13. For example, the list of problem situations surveyed by the ABAABF Survey includes five matters directly relating to property ownership. See B. CuRRAN, supra note 7 , at 103 .

101. Mayhew \& Reiss, supra note 75, at 309, 312-13 (public use of attorneys "is heavily oriented to property"). Mayhew and Reiss found that more than $60 \%$ of respondents' most recent consultations with lawyers involved property.

102. Persons might obtain this information from friends and acquaintances who are familiar with lawyers and legal problems as well as from lawyers themselves. See M. ZANDER, supra note 89 , at 292-96; Zander, supra note 38 , at $1678-79$; see, e.g., B. ChrISTENSEN, supra note 23, at 35-36; MIssolri BAR, supra note 92, at 36; Ladinsky, supra note 71, at 219; Paying less for a lawyer, supra note 5 , at 523 .

103. Zander saw friends, relatives and neighbors as likely lay intermediaries for almost everyone. Depending upon the situation, he also saw social workers, marital counselors, housing officials, union officers, police, doctors, and nurses playing the role of intermediary. M. ZANDER, supra note 89 , at 295-96. 
torney, have included attorneys among potential informed authority figures. ${ }^{104}$

Thus, in the set of possible intermediaries, lawyers form a substantial subset. Unfortunately, the ABA-ABF Survey inquired only into respondents' contacts with lawyers as friends, relatives, neighbors, or social associates. Consequently, available data permit testing of only this portion of the intermediary hypothesis. ${ }^{105}$ However, evidence of the importance of personal contact with lawyers would suggest that other personal contacts are also important to lawyer use. If this notion explains lawyer use, delivery methods creating or increasing such personal contacts will most increase public use of lawyers.

Using the ABA-ABF Survey, which, despite its limitations, ${ }^{108}$ comprises the best quantitative data to date compiled regarding legal problems and lawyer use, we tested the relative strength of the seven explanations of lawyer use.

\section{The Empirical Study}

The absence of authoritative evidence for any one of these explanations of lawyer use suggested the testing of the effect of the seven factors on the behavior of a random sample of individuals. Measures of the relative strength of each hypothesis could suggest criteria for examining the potential of particular methods of legal services delivery.

\section{A. Methodology}

We used, as our data base, the information collected by the ABAABF Survey. The survey data consisted of results from interviews of

104. See, e.g., R. Hunting \& G. Neuwirth, Who Sues in New York CitY? 65 (1962) (accident victims having contact with lawyer or others suggesting legal action are more likely to sue); $c f$. C. Kadushin, Why People Go to Psychiatrists 312 (1969) (other medical professionals figured prominently in referring persons to psychiatrists).

105. One survey question asked if the respondent had ever used an attorney in connection with a business he owned, B. CurRan, supra note 7, at 341 app. (Part IV Question 1) [questions hereinafter cited without cross-reference by part (Pt.) and question (Q.) number]; another asked if respondent had participated in group activity to solve a problem that used an attorney, id. at 336 app. (Pt. II Q. 62). Although respondents affirmatively answering these questions may have been brought into contact with an attorney through a lay intermediary, such as a business partner or neighborhood activist, this reasoning is too speculative to permit us to consider these two questions adequate tests of the lay intermediary hypothesis. As both questions directly addressed contact with lawyers, we consider them evidence only of lawyer contacts, not lay contacts.

106. Some questions, particularly those concerning respondents' estimates of the cost of legal services, had a high nonresponse rate. See p. 141 infra. Nevertheless, the ABA$A B F$ Survey "is the only study [of legal needs] which is representative of the national population" and "is also the most elaborate study to date." M. ZANDER, supra note 89, at 393 . 
a national cross-section of 2,064 adults conducted between October 1973 and March $1974 .{ }^{107}$ Each respondent was asked approximately 170 questions regarding his use of and attitudes toward lawyers, as well as his social and economic background. ${ }^{108}$

With this sample, we employed linear regression and cross-tabulation to measure the strength of the seven explanations. ${ }^{109}$ These sta-

107. Planning for the survey began as carly as 1971 and extensive efforts were devoted to the derelopment of questions and pretesting the questionnaire. The National Opinion Research Center performed the field work associated with the survey. For a full discussion of the implementation of the survey, see B. Curran, supra note 7, at 16-18.

Survey respondents were randomly chosen from households listed in the United States census. See B. Currin \&. F. Spalding, The legal Needs of the Public 30-33 (1974). Because the survey was limited to households and because not all respondents who were selected and screened agreed to participate, the sample is not perfectly representative of the United States population. The very young, very old, males, blacks, hispanics, never married, and persons with less than a high school education are slightly underrepresented, but not to a significant degree. See B. Curran, supra note 7, at 54-74.

108. For a copy of the complete questionnaire, see B. Curran, supra note 7, at 279-382.

109. Linear regression equations describe the best line, if any, that can be drawn among the points of a graph plotting data concerning one or more independent variables against data concerning a particular dependent variable, such as respondent's lawyer use. The explanatory value of such an equation is related to how closely the plot of the data resembles a particular pattern and not a random arrangement of points. Specific calculations reveal the Ievel of statistical significance of the equation-probability that the pattern was a random one-and the percent of variation in the fact one seeks to explain for which the independent variables are responsible-closeness of the pattern of data to the line represented by the equation. See H. Blalock, Social Statistics 384-86 (ruv. 2d ed. 1979); Kim \& Kohout, Multiple Regression Analysis: Subprogram Regression, in N. Nie, C. Hull, J. Jenkins, K. Steinbrenner, \& D. Brent, Statistical Package for THE Social ScIENces 320, 321-23 (2d ed. 1975).

The statistical significance of a regression equation is identified by its F-score. When compared to the size of the relevant sample, the F-score reports the probability that the relationship represented by the equation occurs randomly. This is the level of statistical significance of the equation. Thus, if an equation is statistically significant at the .01 level, the chance that it results from a random distribution is only $1 \%$. See Kim \& Kohout, supra, at 334.36 . Commonly cited as conservative acceptable levels are .05, .01, and .001. See H. BLALock, supra, at 161.

Also of value in analyzing a regression equation is the $R^{2}$ score. The sum of the squares of the distances between the actual data points plotted for the sample and those pre. dicted by the regression equation, $R^{2}$ represents the proportion of variation in the dependent variable that can be explained by the regression equation. For example, an equation with an $\mathrm{R}^{2}$ of .10 is said to explain $10 \%$ of the variation in a dependent variable. See Kim \& Kohout, supra, at 279.

The $\mathrm{R}^{2}$ and $\mathrm{F}$-scores also help identify the importance of each of the independent variables. The variable's F-score measures the statistical significance of its contribution to the entire equation. When creating a regression equation, the computer program used by this Project included variables in order of their F-scores. See Klecka, Discriminant Analysis, in N. Nie, C. Hull, J. Jenkins, K. Steinbrenner, \& D. Brent, Statistical Packige FOR THE Social SCIENCES 434, 453-54. The change in $\mathrm{R}^{2}$ caused by the addition of a particular variable to a particular equation indicates the variation explained by that variable relative to that equation. See Kim \& Kohout, supra, at 336.

Also available for each independent variable are measures of their strength and direction. The $b$ coefficient, or slope, describes the unit change in the dependent variable resulting from a unit change in the independent variable. A large coefficient indicates a strong independent variable. The sign of the coefficient indicates whether the direction 
tistical techniques enabled us to identify the particular characteristics of respondents who did or did not use lawyers, and to test the statistical merit of mathematical representations of the seven factors. ${ }^{110}$ The representations are described below in the discussion of the test of each explanation.

\section{B. Findings}

The results of the tests of the proposed explanations of lawyer use have been divided into categories based upon the strength of the corresponding linear regressions. Those in the weaker group explained less than two percent of lawyer use, while those in the stronger group explained more than five percent.

\section{The Weaker Explanations}

Four factors-income, price, awareness, and attitude-correlated weakly with lawyer use.

Income. To test the first variation of the income hypothesis, that purchases of legal services increase as an individual's income increases, we performed a mathematical regression comparing lawyer use and income. This regression revealed that even large differences in income had only a mild impact on whether an individual used a lawyer. Although the relationship was significant at the .01 level, it explained only 0.2 percent of the variation in lawyer use. ${ }^{111}$

To test the second version of the income hypothesis, that because the poor have access to legal aid, lowest lawyer use is concentrated in middle income groups, we constructed a cross-tabulation compar-

of the independent variable's correlation with the dependent variable is positive or negative. $I d$. at 323,330 .

We performed cross-tabulations only when the regression results did not supply the information we sought. A cross-tabulation identifies the frequency with which two or more sets of respondents possessing distinct characteristics share one or more other characteristics. See N. NiE, C. Hull, J. Jenkins, K. Sternbrenner, \& D. Brent, Statistical Package for the Social Sciences 218-22 (2d ed. 1975).

110. Statistics do not reveal the truth of a hypothesis or the direction of causation. The most common use of statistics is to determine merely whether or not a hypothesis has been disproven by a particular calculation. Much of the following analysis, therefore, consists of our inferences from statistical measures and not irrefutable conclusions dictated by the measures themselves. See H. BLALOCK, supra note 109, at 4-8, 154-56.

111. USE $(0-1)=.60+.01$ Income (1-10); $F$ of Equation $=6, R^{2}=.002$. The figures in parentheses indicate the lower and upper bounds of the values of the variables as coded by the ABA-ABF Survey or as recoded by the Project prior to regression analysis. Explanation of recoding is found in Appendix I, infra, or in the Project Code Book (on file with Yale Law Journal). 
ing income with lawyer use. Although the percentage of lower and middle income persons who had used a lawyer was almost the same, the test revealed that higher income persons had more frequently employed a lawyer. ${ }^{112}$ In light of this information, we modified the regression test to compare lawyer use with the presence of high income. The resulting equation revealed that even the difference in use of lawyers between high income and non-high income persons was not very large. The equation explained only one percent of the variation in lawyer use. ${ }^{113}$

Price. The price hypothesis of legal services use suggests that respondents who believed a lawyer's services cost less would be more likely to have obtained legal assistance. Unfortunately, data to test this hypothesis were limited. The ABA-ABF Survey recorded respondents' estimates for only a limited number of services, ${ }^{114}$ and more than one-fourth of the respondents did not answer the relevant questions. ${ }^{115}$ Moreover, legal services are not homogeneous and may vary in nature and price. A will, for example, may require anything from simple "boilerplate" to complicated estate planning. Estimates, therefore, may not be strictly comparable.

Despite these limitations, we constructed a regression comparing cost estimates for wills and consultations with lawyer use. ${ }^{116}$ The re-

112. Cross-Tabulation of INCOMe wTth LAWYer Use INCOME (annual, in dollars)

Percentages

Have Used a Lawyer?

$\begin{array}{llllll} & 0.4680 & 4681-9950 & 9951-17400 & 17400+ & \text { N (weighted) } \\ \text { Yes } & 65.6 & 62.9 & 61.1 & 80.0 & 2136 \\ \text { No } & 34.4 & 37.1 & 38.9 & 20.0 & 1120 \\ \text { N (weighted) } & 1221 & 812 & 814 & 409 & 3256 \\ & \text { Raw Chi Square }=47.34 & & \text { Significance }=.01 & \end{array}$

Chi-square $\left(\chi^{2}\right)$ measures the degree of association between variables in cross-tabulation where, as above, at least one of the variables is nominal, that is, has no scale. A high chi-square value generally indicates close correlation between the row variable and the column variable of a cross-tabulation. See H. Bralock, supra note 109, at 280-81.

113. USE $(0-1)=.62+.18$ Income $(0-1) ; F$ of Equation $=50, R^{2}=.01$.

114. Those services were consultation, will making, real estate representation, and tort representation. B. CuRran, supra note 7, at 361 app.

115. ABA Special Committee to Survey Legal Needs, Special Report, ALTERNATIVES, Jan. 1976 , at 18 .

116. See Appendix I, p. 156 infra. Estimates for representation in a real estate transaction and in a tort suit were not used. Estimates for those services were given as percentages, and not as dollar amounts. B. Curran, supra note 7, at 361. Also, almost $40 \%$ of the respondents were unwilling or unable to make estimates for those services. ABA Special Committee to Survey Legal Needs, supra note 115 , at 18. 
gression showed that as price estimates decreased, lawyer use increased slightly. Significant at the .01 level, the equation explained only one percent of the variation in lawyer use. ${ }^{117}$

Awareness. The next hypothesis tested was that consumers, who are better able to identify the legal implications of a problem, are more likely to use a lawyer. In constructing a regression equation, we grouped individuals according to their responses to questions asking whether they would have sought legal advice in six hypothetical situations in which a lawyer could have been helpful, ranging from a traffic accident to employment discrimination. ${ }^{18}$ The regression then compared with the individual's lawyer use the number of hypotheticals where an individual would have consulted a lawyer. The resulting equation revealed that increases in legal awareness slightly increased use of a lawyer. Significant at the .01 level, the equation explained only one percent of the variation in lawyer use. ${ }^{119}$

Attitude. Using twenty-eight attitude questions, we tested the hypothesis that persons with more positive attitudes toward lawyers are

117. USE $(0-1)=.72-.0003$ Will $(5-700)(F=9)-.001$ Consultation $(5-250)(F=6)$; $\mathrm{F}$ of Equation $=10 ; \mathrm{R}^{2}=.01$.

118. See Appendix I, p. 159 infra.

119. USE $(0-1)=.44+.1$ Awareness $(0-6) ; \mathrm{F}$ of Equation $=52, \mathrm{R}^{2}=.01$. Two hypotheses might explain the weakness of the awareness variable. First, even individuals who are more likely to recognize that a lawyer could be helpful in a particular situation, and who have high awareness scores, might actually use lawyers only in traditional legal situations in which most persons recognize that a lawyer would be helpful. Second, persons who are more likely to recognize the helpfulness of a lawyer in nontraditional legal situations might be less likely to experience such situations, and consequently do not use lawyers more often than those with low awareness scores. For example, highawareness persons may seldom be victims of job discrimination. It appears, however, that the first situation is more probable. Individuals with greater awareness scores experienced at least as many problem situations as individuals with low awareness scores. Respondents who had actually experienced job discrimination were twice as likely to mention using a lawyer in response to the job discrimination hypothetical than those who had never experienced the problem-11.1\% compared to $5.2 \%$. Further, those who perceived themselves as victims of past job discrimination had slightly higher awareness scores.

Cross-Tabulation of Legal Awareness Score with Number of Non-Acute Problems Encountered

LEGAL AWARENESS SCORE

Percentages

Number of Non-Acute Problems Encountered

\begin{tabular}{llrlllllr} 
& 0 & 1 & 2 & 3 & 4 & 5 & 6 & N (weighted) \\
$0-4$ & 5.3 & 12.2 & 21.0 & 23.0 & 24.7 & 12.6 & 1.1 & 1050 \\
$5-9$ & 4.1 & 7.8 & 21.5 & 28.2 & 24.9 & 11.6 & 1.9 & 1036 \\
$10+17$ & 3.4 & 10.1 & 18.9 & 28.8 & 21.9 & 15.7 & 1.3 & 970 \\
$18-121$ & 3.3 & 9.6 & 19.8 & 25.9 & 20.6 & 18.9 & 1.9 & 1015 \\
N (weighted) & 165 & 404 & 828 & 1076 & 938 & 596 & 64 & 4071 \\
\multicolumn{5}{c}{ Raw Chi-Square $=58.8$} & \multicolumn{5}{c}{ Significance = .001 }
\end{tabular}


more likely to use lawyers. First, we applied factor analysis to identify groupings of responses to the attitude questions. The resulting groups clustered responses into an overall attitude measure and categories relating to attitudes toward lawyers' personality traits, lawyers' ethics, judges and trials, appropriate occasions for using a lawyer, and the heipfulness of lawyers and the legal system. ${ }^{120}$

We then performed a regression comparing all six attitude categories with lawyer use. Within the resulting equation, changes in attitudes toward lawyers' personality traits and ethics, as well as the helpfulness of lawyers and the legal system, made no statistically significant difference in lawyer use. However, positive attitudes overall and attitudes toward appropriate occasions for using a lawyer slightly increased use, as did negative evaluations of judges and trials. The contribution to the equation of overall attitude was significant at the .05 level, while that of appropriateness and judges and trials was significant at the .01 level. The entire equation, athough significant at the .05 level, nevertheless explained only one percent of the variation in lawyer use. ${ }^{121}$

\section{The Stronger Explanations}

Three factors-experience, property ownership, and personal contacts with lawyers-correlated more strongly with lawyer use.

Experience. To measure whether an individual's particular experiences with situations that could have involved a lawyer increased his use of a lawyer, we compared a respondent's lawyer use with the acute and non-acute legal problems he had faced, as well as his age. We defined as acute those situations in which an individual must confront the legal system if he wishes to obtain a particular form of relief over which the courts have almost exclusive control. For example, an individual must apply to a court to seek a divorce or to defend a criminal charge. ${ }^{122}$ In contrast, an individual can, but need not, apply to a court for relief in non-acute situations, such as consumer complaints. ${ }^{123}$ Because the survey's coverage of acute and non-acute problems was not exhaustive, we used age as a further indicator of whether a person would have experienced a situation in which a lawyer could

120. See Appendix II, pp. 160-63 infra. A score in each attitude category was compiled for each respondent. A high score indicated a positive attitude.

121. USE $(0-1)=.7+.01$ Appropriateness $(3-15)(F=8)-.01$ Judges/Trials $(\tilde{0}-20)$ $(F=24)+.01$ Overall Attitude $(13-65)(F=14) ; F$ of Equation $=16, R^{2}=.01$.

122. For a complete list of the acute situations, see Appendix I, p. 159 infra.

123. For further discussion of these nonacute situations, see Appendix I, p. 158 infra. 
have been helpful. The longer one lives the more likely one is to encounter a legal problem. ${ }^{124}$

The resulting regression revealed that persons with more experience used a lawyer more frequently. Together, age, number of nonacute situations faced, and experience with an acute problem explained twenty percent of variation in lawyer use. The equation was significant at the .01 level. The contribution to the equation of each of the three variables was significant at the .01 level. ${ }^{125}$

Property Ownership. In testing the hypothesis that an individual who owns real property more frequently uses a lawyer, we employed a regression that compared property ownership with lawyer use. The resulting regression showed that property ownership had a strong influence on lawyer use, though not as much as experience. Persons who owned property were far more likely to use a lawyer than those without real property. The equation explained eleven percent of

124.

PAst Use of a LAwYer by Age:

Cross-Tabulation of Lawyer Use with Age

USED A LAWYER?

\begin{tabular}{lcll}
\multicolumn{4}{c}{ Percentages } \\
Age & Yes & No & N (weighted) \\
$18-26$ & 35.6 & 64.4 & 919 \\
$27-37$ & 68.7 & 31.3 & 856 \\
$38-48$ & 71.6 & 28.4 & 791 \\
$49-59$ & 75.8 & 24.2 & 765 \\
$60-90$ & 74.3 & 25.7 & 731 \\
N (weighted) & 2613 & 1458 & 4062 \\
Raw Chi-Square & $=435.8$ & Significance $=.001$
\end{tabular}

Cross-Tabulation of Non-Acute Problems Encountered with Age NUMBER OF NON-ACUTE PROBLEMS ENCOUNTERED

\begin{tabular}{lcccccl} 
Age & \multicolumn{7}{c}{ Percentages } \\
$18-26$ & $0-3$ & $4-7$ & $8-11$ & $12-20$ & $21-121$ & N (weighted) \\
$27-37$ & 50.3 & 11.0 & 8.0 & 11.3 & 19.4 & 919 \\
$38-48$ & 27.3 & 22.4 & 12.8 & 12.7 & 25.3 & 856 \\
$49-59$ & 18.5 & 26.3 & 17.6 & 17.9 & 19.7 & 791 \\
$60-90$ & 9.4 & 24.2 & 25.3 & 26.0 & 15.1 & 765 \\
N (weighted) & 6.3 & 22.3 & 34.0 & 26.4 & 11.0 & 731 \\
& 849 & 843 & 710 & 850 & 810 & 4062 \\
& Raw Chi-Square $=1310$ & Significance $=.001$ &
\end{tabular}

One commentator, however, has noted that the cumulative effect of age is mild compared to the younger generation's increased encounters with legal problems and greater willingness to use a lawyer. See Avichai, Trends in the Incidence of Legal Problems and in the Use of Lawyers, 1978 AM. B. FOUNDATION RESEARCH J. 289, 294-95.

125. USE $(0-1)=.14+.05$ Non-Acute $(1-10)(F=386)+.04$ Age $(1-10)(F=229)+.21$ Acute $(0-1)(F=186) ; F$ of Equation $=340, R^{2}=.20$. 
lawyer use, and the correlation was significant at the .01 level. ${ }^{126}$

Contact with Lawyers. The last hypothesis tested was that an individual who had contacts with lawyers was more likely to use a lawyer. We compared lawyer use with factors that indicated a respondent's probable familiarity with lawyers or persons who know lawyers. These included whether a respondent had a friend, relative, or neighbor who was a lawyer, had used a lawyer in business, or had participated in a group that had used a lawyer. ${ }^{127}$

The resulting regression revealed that persons with lawyer contacts used lawyers more frequently. Significant at the .01 level, the regression equation explained six percent of the variation in lawyer use. The contribution of each variable to the equation was significant at the .01 level. The positive correlation of lawyer use with personal acquaintance was very strong and that for group or business use was relatively weak..$^{128}$

\section{A Mathematical Model of Lawyer Use}

In addition to testing the seven determinants individually, we also performed a regression comparing the stronger variables together with lawyer use. This regression enabled us to examine the relative strength of the more powerful explanations, and also to identify whether the pattern represented by one individual equation included part or all of the other factors.

The resulting regression suggested a model of lawyer use that was somewhat stronger than any of the three explanations taken individually. The cumulative regression equation explained twenty-three percent of lawyer use, and was significant at the .01 level. That the amount explained was lower than the sum of the amounts explained by each separately suggests that the three factors were related. ${ }^{129}$ The individual contribution of each factor to the equation, however, was significant at the .01 level. Experience explained twenty percent of the variation in lawyer use, compared to only 1.8 percent for property

126. USE $(0-1)=.39+.35$ Property $(0-1) ; \mathrm{F}$ of Equation $=490, \mathrm{R}^{2}=.11$

127. See Appendix I, pp. 156-57 infra. Because the survey measured respondent's use of an attorney for personal matters, there was no automatic correlation between the variables. A person who used a lawyer for business but not for personal matters would not be a lawyer user as defined by this Project.

128. USE $(0-1)=.5+.18$ Personal Contacts $(0-1)(F=125)+.06$ Business Use $(0-1)$ $(F=41)+.10$ Group Use $(0-1)(F=33) ; F$ of Equation $=85, R^{2}=.06$.

129. See, e.g., H. BLALock, supra note 109, at 485; Kim \& Kohout, supra note 109, at $340-41$. 
ownership and 1.5 percent for lawyer contacts. ${ }^{130}$ Experience, therefore, explained by far the greatest variation in lawyer use. Lawyer contacts and property ownership, while also salient, were less powerful. ${ }^{131}$

\section{Implications for Alternative Legal Delivery Systems}

An examination of alternative legal delivery systems in light of the somewhat unexpected results of our analysis enables us to assess the systems' potential for increasing the public's use of lawyers. ${ }^{132}$ Con-

130. Group and business use of a lawyer, unlike personal lawyer contacts, were very weak determinants of lawyer use and were not included in this regression.

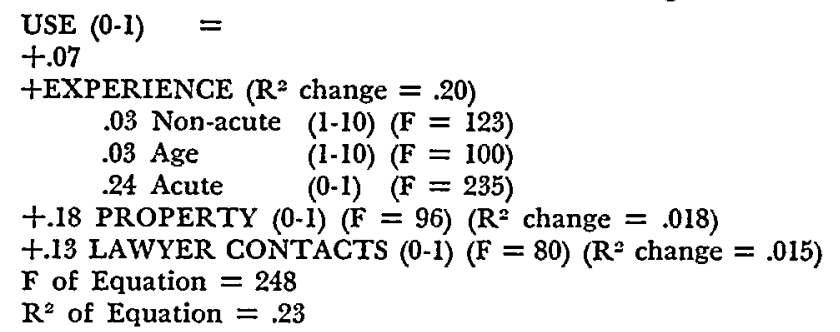

131. When the order of independent variables in the regression changes, the relative strength of the independent variables often does as well. Therefore, for example, when the equation included lawyer contacts first, property ownership second, and experience third, the variation explained by p operty ownership increased to $8 \%$, and that of lawyer contacts to $6 \%$, while experience decreased to $8 \%$.

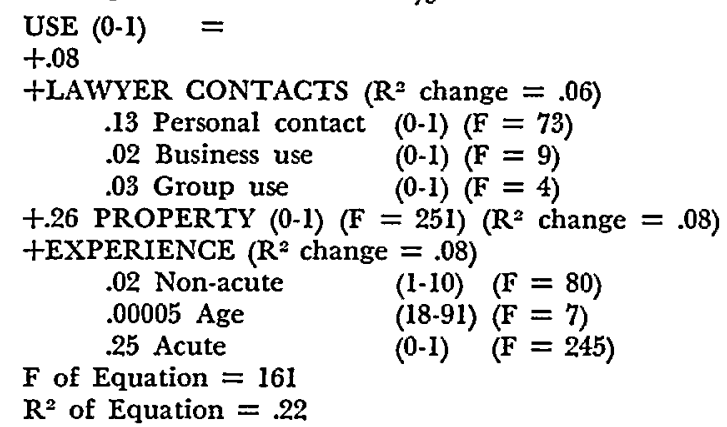

In this particular equation, business and group use were added to lawyer contacts, and age was not recoded. These changes probably increased very slightly the variation explained by lawyer contacts and property, and decreased the variation explained by experience.

132. Despite its large sample size, comprehensive questionnaire, and rigorous methodology, certain limits of the ABA-ABF Survey mandate caution in attempting to draw conclusions from any study that employs these data. A survey merely obtains responses from a sample of respondents for one period of time. Such responses are subject to change, and the attitude and price responses of the ABA-ABF Survey may be particularly prone to such temporal shifts because of changes in the market for legal services. In particular, it should be emphasized that the current market for legal services differs substantially from that of 1973 to 1974 as a result of Bates v. State Bar of Ariz., 433 U.S. 350 (1977), which overturned the profession's ban on advertising.

Finally, it must be emphasized that the conclusions of the Project are not derived directly from the empirical data, but rather from inferences based on the model derived from the data. 
trary to the observations of some commentators, attitude, awareness, and income have only a minor effect on lawyer use. The influence of price on lawyer use is difficult to determine given the limits of the data. The potential of alternative systems, ${ }^{133}$ therefore, must be evaluated in light of the three strong explanations of lawyer use-experience, property ownership, and lawyer contacts.

\section{A. The Limits of Alternative Delivery Systems}

The results of our empirical study imply a limited role in increasing lawyer use for all alternative delivery systems. Our analysis indicates that lawyer use is primarily a function of an individual's experience, which is measured by the number of acute and nonacute problems he has encountered as well as his age. These experience factors, taken together, account for twenty percent of the variation in lawyer use. ${ }^{134}$ Experience is largely an external factor, unalterable by legal service delivery systems.

Alternative delivery systems, however, may modify the experience component by altering the way in which a situation is perceived. An example is the concept of preventive legal services or an annual legal checkup, which both prepaid plans and clinics have considered promoting. ${ }^{135}$ Such an approach, if successful, might greatly increase the number of perceived legal problems. ${ }^{136}$

Another strong determinant of lawyer use in our study is real prop-

133. This Project does not directly address the question of which of the three alternative delivery systems has the greatest potential for expansion, because it is impossible to make such a determination on the basis of the data collected in the ABA-ABF Survey. All three alternatives have been marketed with some success. See B. Christensen, supra note 23, at 199.200 (suggesting that advertising of lawyer referral services may increase use five to ten times); Paying less for a lawyer, supra note 5, at 526 (estimating that five million families are covered by prepaid plans); Slavin, supra note 4 , at 47 (describing proliferation of legal clinics). Important policy questions remain that will affect the growth of these three alternatives. Bar associations must decide what resources to devote to LRSs. The growth of prepaid plans will be affected by decisions regarding how they are to be treated under state insurance laws and federal tax laws. See L. Derrch \& D. WEINSTEIN, supra note 28, at 26-27 (discussing problem of requiring prepaid plans to satisfy state insurance requirements); Hendricks, Federal Income Tax Consequences for Group Legal Service Plans, in Legal Delivery Systems: Available Alternatives 285, 290 (1977) (Congress must consider whether to extend provision exempting employer contributions and legal benefits of prepaid plans from income tax). Bar associations must decide what types of advertising are to be permissible. See note 170 infra. This Project discusses only one of the aspects relevant to such policy decisions-which alternatives have the greatest potential for increasing lawyer use.

134. See p. 144 supra.

135. See Washington Conference, supra note 3, at 63-66 (statement of Harriet Thayex); Interview with Wayne Willis, partner at Hyatt Legal Clinics of Cleveland, Ohio, in New Haven, Conn. (March 5, 1979) (notes on file with Yale Law Journal).

136. See Sackman, IVe Practice Preventive Law, 1 New Directions in Legal Services 61, 62 (1976). But see B. Christensen, supra note 23, at 11 (bar efforts to promote annual legal checkup unsuccessful). 
erty ownership, which accounts for eleven percent of the variation in lawyer use alone and 1.8 percent when combined with experience and lawyer contacts. ${ }^{137}$ Like experience, however, real property ownership is an external factor that cannot be influenced by alternative delivery systems. ${ }^{138}$ The remaining determinants of lawyer use that could be more readily altered by alternative systems-price, attitude, awareness, and lawyer contacts ${ }^{139}$-correlate less strongly with lawyer use. ${ }^{140}$

More particularly, the results of our analysis imply that two strategies often recommended for increasing lawyer use-improving the image of lawyers and raising the legal awareness of the public-may not significantly affect lawyer utilization. Many observers have argued that lawyers are under-used because the public generally holds the legal profession in low esteem. ${ }^{141}$ They have proposed, therefore, that the bar seek to improve its image as a means of increasing the use of lawyers. Frequently suggested is institutional advertising by state and local bar associations. ${ }^{142}$ Our analysis suggests, however, that a person's attitude toward the legal profession has little effect on whether he uses a lawyer. ${ }^{143}$ Attempts to improve the profession's public image and alter the public's attitude toward lawyers, therefore, are likely to achieve little success in increasing lawyer use. ${ }^{144}$

137. See pp. 144-46 supra.

138. Ownership of property correlates with lawyer use because property ownership often leads to problems that are legal in nature and because property may be an indirect source of lawyer contacts. See p. 137 supra. Alternative delivery systems may also be able to affect marginally the number of problems that are viewed as legal. See note 135 supra. Alternatives may also operate as an indirect source of lawyer contacts. See pp. 149-54 infra.

139. The importance of price, however, is probably understated in the model due to the limitations of the data. See p. 141 supra. To the extent that price is an important element in determining the amount of lawyer use, the potential for alternative delivery systems may be less limited than is suggested here. Some alternatives may lower prices substantially. See p. 154 infra.

140. However, we are hesitant to minimize the potential of alternative delivery meth. ods too quickly. To some extent, the experience variables-acute problems, non-acute problems, and age-are proxies for the other independent variables in the regression equation, and vice versa. This overlap is suggested when the $R^{2}$ of variables changes as the order of inclusion of the variables into the equation is changed. See note 131 supra. Furthermore, the survey results may be somewhat dated, see note 132 supra, and some survey questions received inadequate responses, see p. 141 \& note 106 supra.

141. See, e.g., B. Christensen, supra note 23, at 36; Berg, supra note 44 , at 1 .

142. See ABA Commission on Advertising, Bar Association Advertising: A How.To MANual I (1979) (more than SI.I million spent on institutional advertising by state and local bar associations, in part to build image of the bar). Some have suggested that prepaid plans may be effective in changing attitudes. See L. DeITCH \& D. WEINSTEIN, supra note 28, at 74; W. Pfennigstorf, supra note 48, at 3; Washington Conference, supra note 3 , at 410 (remarks of Helen Nelson).

143. See p. 143 supra.

144. But see J. Haefner, Advertising Effectiveness Study Prepared for the Illinois State 
Others have argued that increased public awareness of the legal dimensions of various problems will lead to increased lawyer use. ${ }^{145}$ Our analysis, however, shows that legal awareness has a relatively minor effect on lawyer use. ${ }^{146}$ Consequently, general educational campaigns and institutional advertising aimed at increasing public awareness of legal problems may also yield relatively minor increases in lawyer use. ${ }^{147}$

\section{B. Enhancing Lawyer Contacts Through Alternative Delivery Systems}

Although the individual experience and property ownership factors are virtually unalterable by legal services delivery systems, the three alternative systems may have some impact on the third important determinant of lawyer use-personal contacts with attorneys. ${ }^{148}$ Personal contacts serve as a general information source concerning the kinds and costs of services provided by lawyers. An attorney with whom one has personal contact can also serve as an intermediary, acquainting an individual with the legal system and particular local lawyers capable of resolving his problem. ${ }^{149}$ To the extent that an alternative delivery system can serve the same functions as a lawyer contact, it probably will succeed in increasing lawyer use.

Bar Association 10.11 (Apr. 4, 1977) (institutional advertising changes attitudes and expressed intention to have will prepared) (on file with Yale Law Journal). This study, however, did not measure changes in lawyer use.

145. See B. Christensen, supra note 23, at 36; Carlin, supra note 6, at 644-45. One way of encouraging legal awareness might be through institutional advertising. See ABA Commission on ADvertising, supra note 142, at 1. Others have argued that LRSs can serve as a general educational resource concerning the legal implications of problem situations. See Berg, supra note 44 , at $4-5$.

146. See p. 142 supra.

147. A distinction must be drawn between educational campaigns and advertising that seek only to inform the public of the legal implications of certain problem situations, and advertising that provides more specific information, such as cost or how a lawyer may be helpful in a specific context. The latter may have some impact on lawyer use, because it may serve as a substitute for information supplied by lawyer contacts.

148. See p. 145 supra.

149. The traditional notion that a lawyer ought to secure clients through a wellmerited reputation for competence and honesty was based on the experience of the small town practitioner who had contacts with the entire community. See B. CHRISTENSEN, supra note 23, at 128-30. Although such contacts served as adequate sources of information and sound basis for lawyer selection in the small town, they can hardly serve the same function in modern urban America where contacts are less pervasive. Id. at 130-31. As a consequence, alternative delivery systems must act as a substitute for lawyer contacts. See Goodman, supra note 50, at 15 (prepaid plans perform same functions formerly performed in small town by lawyer reputation); Hobbs, Lawyer Advertising: $A$ Moderate Proposal, alternatives, Feb. 1976, at 3 (advertising may serve same function as lawyer contacts for well-to-do). 


\section{Lawyer Referral Service (LRS)}

By enabling a client to consult with a lawyer at a nominal fee, the LRS provides potential for lawyer contact and access to information. Some information may be provided to the client at the initial screening interview, ${ }^{150}$ but the potential for providing information at this point is limited by the fact that so few LRSs have staff attorneys. ${ }^{151}$ Nevertheless, the client can use this opportunity to discover what, if anything, a lawyer can do to resolve his problem, and how much these services will cost. Although this may be useful, the potential client has similar opportunities with other alternative systems that he may be able to use at less cost. ${ }^{152}$ Unfortunately, the LRS provides information at a relatively high search cost, because the client must endure substantial inconvenience in order to arrange an initial screening. ${ }^{153}$ This cost limits the effectiveness of the LRS as a potential information source.

By actually making an appointment with an attorney for a prospective client, the LRS may be useful as a resource for lawyer selection. The service thus helps to overcome a potential client's initial hesitation in contacting an attorney. ${ }^{154}$ Unlike a lawyer contact who is a friend, relative or neighbor, however, the LRS lacks an ongoing relationship with the consumer. ${ }^{155}$ As a consequence, consumers may consider an LRS referral less reliable than a recommendation made by a lawyer friend or relative whom they know and trust. Consumer mistrust may be justified, as membership in LRS panels is not subject to careful screening; LRS panels represent only a cross-section of the bar. ${ }^{158}$

150. See Commitment and Vision: The New Look in LRS, 3 NEW DiREctIons IN LEg.AL SERvices 49, $5 \mathrm{I}$ (1978) (interview with Paul V. Carlin, Director of Consumer Lawyer Referral Service for District of Columbia Bar).

151. See note 42 supra. But see Carlin, supra note 6, at 651 (new ABA Standards urge upgrading of screening function).

152. See pp. 151, 153 infra.

153. See B. Christensen, supra note 23, at 193-94 (inconvenience of initial screening interview may be formidable barrier to use of LRSs); WASHINGTON CONFERENCE, supra note 3 , at 35 (remarks of Frank Jones).

154. See Christensen, supra note 39 , at $279,287$.

155. Most users of LRSs are sceking a lawyer for the first time. See Murphy, supra note 43 , at 253 .

156. See B. ChRISTENSEN, supra note 23, at 178-83; Christensen, supra note 39 , at 288 . Similar problems exist with the composition of special panels and matching a client with a lawyer who is a specialist. B. Christensen, supra note 23, at 183-87; Christensen, supra note 39 , at 288 .

Of course, some of these problems could be remedied by upgrading the minimum standards required for panel membership and adding other safeguards. See Carlin, supra note 6 (discussing various recommendations for improving LRS). 


\section{Prepaid Plans: Open- and Closed-Panel}

Open-panel plans may be effective information sources. Prior to eurollment in an open-panel plan an individual is usually informed about the legal services to which he will be entitled and their cost. ${ }^{157}$ Nevertheless, open panels may not provide full information on costs because benefits are sometimes listed in dollar amounts or hours of legal work. ${ }^{158}$ The consumer must still estimate how many hours or how many dollars a particular service will require in order to ascertain whether such expenses are fully covered by his policy.

More important, most open-panel plans offer members a limited number of free consultations and advise clients on what a lawyer can do to resolve a particular problem. ${ }^{159}$ Open-panel plans should increase lawyer use by offering this important information source as an integral part of the plan's operation.

Open-panel plans may also serve as either a formal or informal referral service. Most open-panel plans have this feature. ${ }^{160}$ In contrast to the LRS, however, these referrals come from an organization with which the consumer has an ongoing relationship. Consumers may therefore consider such open-panel referrals more reliable, and the likelihood that they will actually take advantage of the referral advice and consult a lawyer may be greater. Furthermore, open-panel plans have a financial incentive to provide referrals the consumer finds adequate. Poor referrals would threaten continued enrollment in the plan. ${ }^{161}$

Closed-panel plans also provide specific cost information and the opportunity for free consultations. ${ }^{162}$ Information on cost may be more detailed than with open panels because some closed panels limit coverage to specific matters and not to specific dollar or hour amounts. ${ }^{163}$ Consultations under a closed-panel plan may involve low-

157. See DeMent, supra note 48 , at 631 .

158. See note 51 supra.

159. See, e.g., L. Deirch \& D. Weinstein, supra note 28, at 52, 68 (Ohio Legal Services Fund, Utah Prepaid Legal Services Plan); Broadman \& Ohman, supra note 49, at 136-37 (New York County Legal Services Corporation Prepaid Legal Services Plan).

160. See, e.g., L. DeITch \& D. Weinstern, supra note 28, at 41; Murphy, supra note 43, at $262-63$ (bar-sponsored open-panel plan run in conjunction with LRS). To the extent that the lawyer is chosen by a referral system, however, the primary justification for open panels-freedom of choice-is vitiated.

161. Bar associations that sponsor open-panel plans may have a more diffused incentive to make effective referrals, and are less able to do so because of the problems inherent in screening their own members. See B. Christensen, supra note 23, at 183.

162. See DeMent, supra note 48 , at 631 .

163. See, e.g., Broadman \& Ohman, supra note 49, at 117-43 (listing closed panels using this system). 
er search costs than consultations obtained under open-panel plans or through LRSs because closed-panel attorneys may be willing to take certain steps to ensure easy access to their services. ${ }^{104}$ As a further step, closed-panel plans often inform members about the benefits of consulting a lawyer through newsletters, meetings, and seminars. ${ }^{105}$

To a greater extent than LRSs and open-panel plans, closed-panel arrangements reduce their members' search costs because the plan assumes total responsibility for selecting its members' attorneys. Many consumers may prefer to leave attorney selection in the hands of a trusted intermediary. ${ }^{166}$ The strong relationship between the member and sponsoring group can be expected to create more trust than found in LRSs and open-panel arrangements. This important combination of free consultation and general dissemination of information could enable closed-panel plans to provide their members with the greatest amount of information at the lowest search cost.

\section{Legal Glinics}

Legal clinics, by advertising, ${ }^{167}$ provide consumers with extensive information on the price of various legal services at relatively low search cost. ${ }^{168}$ Advertising may, however, convey only limited price

164. See L. DeITCH \& D. WEINSTEIN, supra note 28, at 41 ("Lawyers who receive all or a good portion of their income from the plan may be more willing to schedule hours to meet members' requirements, organize facilities to put clients at ease, and locate near the place of employment or other convenient location."); Comment, supra note 49, at 865 (Laborers' Local 423 Plan located office in same building as union office and hiring hall).

165. See, e.g., WASHington CONFERENCE, supra note 3, at 67-69 (statement of Harriet Thayer) (Consumers' Group Legal Services Plan use of seminars and newsletters); Sackman, supra note 136, at 61-62 (1115 Prepaid Legal Service Care's use of booklets, newsletters, and seminars); Comment, supra note 49 , at 868 (prepaid plan's use of newsletters, seminars, and workshops to inform members about legal rights in specific situations). The information conveyed must concern the specific benefits from consulting a lawyer, and not just general information on recognizing legal problems. See note 147 supra.

166. See L. DeITch \& D. Weinstein, supra note 28 , at 41 (members of plan who lack experience may prefer to have group designate lawyers it considers competent); Bernstein, supra note 2, at 474 ("[T] he problems surrounding the selection of an attorney are so difficult that union members generally would prefer to be represented by lawyers whose competence and qualifications have been ascertained by their unions.")

167. To the extent that advertising operates as a substitute for lawyer contacts, both traditional firms and clinics may use it to increase lawyer use. Current evidence indicates, however, that most traditional practitioners do not advertise. See Slavin, supra note 4 , at 47 (only $3 \%$ of attorneys surveyed have used advertising). Clinics, on the other hand, depend on advertising as an integral part of their operations. See Muris \& McChesney, supra note 66 , at 193-95. Moreover, the price advantages of clinics should make them the preferred delivery system, at least for routine services. See p. 154 infra.

168. See Consumer Information Remedies 210 (June 1, 1979) (FTC briefing book) (on file with Yale Law Journal). 
information. ${ }^{169}$ Clinics can also provide information concerning the benefits of lawyer services both in their advertising ${ }^{170}$ and in free or low-fee consultations. ${ }^{171}$ Clinics have further sought to minimize the search costs involved in seeking out their services by using storefront locations and having flexible hours. ${ }^{172}$

Clinics can serve a lawyer referral function by providing consumers with limited information about the clinic's lawyers in their advertising. ${ }^{173}$ As with the information provided by LRSs, however, this advertising is not offered by someone with whom the consumer has an ongoing relationship. The consumer will likely find such advertising information even less reliable than that from LRSs, because advertising is provided by someone who has an interest in supplying only positive information. ${ }^{174}$

\section{Conclusions}

The foregoing assessment of the three alternative delivery systems yields suggestions for increasing lawyer use. For individuals who belong to a group that could readily employ a prepaid plan, ${ }^{175}$ closed

169. See ABA Commission on Advertising, Individual Lawyer Advertising: A How-To Manual 10 (1979) (difficult to provide price information through mass media).

170. Advertising information such as the quality of services may be limited by legal constraints. See Bates v. State Bar of Ariz., 433 U.S. 350, 383.84 (1977) (bar has special role to play in regulating advertising to see that it is not deceptive).

In the wake of Bates, some state bar organizations have proposed rules that would substantially limit the amount and type of information contained in advertising. See Ostrowsky, States Respond to Bates, 2 NEw Directions in Legal Services 137, 137-39 (1977).

Externalities may also inhibit clinics from including information on the benefits of consulting an attorney, because the benefits of such advertising may inure to the pro. fession as a whole. See Interview with Wayne Willis, supra note 135 (advertising of Hyatt Clinic increases number of clients obtained by many local firms).

171. See D. Maron, Legal Clinics: Analysis and Survey 8 (2d ed. 1977).

172. See Meyers, stupra note 68 , at 111 .

173. The amount of information provided is limited by the constraints of the medium and the cost of advertising. See ABA Commission on Advertising, supra note 169, at 8 (copy for newspaper ads must be brief). But cf. Dryer, Clients and Lawyers at Odds on Advertising, 2 NEw DiRections IN LEGAL SERvices 146, 150 (1977) (consumers prefer high information ads).

174. See Christensen, supra note 39, at 284. See also Ladinsky, supra note 71, at 216-18 (advertising may not remedy consumer's inability to judge legal services market).

175. For examples of groups that have profitably employed closed-panel plans, see p. 130 supra.

It will be difficult to market prepaid plans to individuals because of the problem of adverse selection. If plan members enroll on an individual basis, those people who anticipate a large number of future legal problems will be the most likely to enroll. As a consequence, the plan may be seriously overburdened by a large number of problems and may cxperience solvency problems. See L. DeITCH \& D. WEINSTEIN, supra note 28, at 37 (discussing adverse selection problems of voluntary plans). Automatic enrollment of group members may also be preferable for administrative reasons. Id. In practice, marketing voluntary enrollment plans has been difficult and some plans have experienced 
panels offer the best source of information as to the costs and benefits of consulting a lawyer, and also the most direct form of lawyer selection. Closed-panel prepaids are thus most likely to fulfill the instrumental function of lawyer contact and thereby increase lawyer use. Legal clinics, rather than LRSs, are more likely to serve the function of lawyer contact through their advertising for those individuals who are not members of groups for which prepaid plans are marketable or feasible. ${ }^{176}$

\section{Theoretical Impact of Price on Delivery Systems}

Economic theory suggests that price is an important factor affecting the rate of use of any service, including legal services. ${ }^{177}$ Limitations of the survey data made it difficult for us to estimate the importance of price in the decision to use a lawyer. ${ }^{178}$ The greater the importance of price considerations, however, the greater should be the preference for closed-panel prepaid plans and clinics. Both of these alternatives offer the best opportunity for reducing the price of legal services by generating a high volume of similar legal work and thereby permitting both economies of scale and standardization, with a concomitant reduction in costs. ${ }^{179}$ Open-panel prepaids and LRSs, by contrast, lack

solvency problems. See DeMent, supra note 48 , at 634-35. But see W. Pfennigstorf, supra note 48 , at 28 (successful marketing of legal insurance to individuals in Europe). The European experience is not analogous, however, because coverage is generally restricted to legal expenses for events such as automobile accidents. Id. at 47.

The market for prepaids is nonetheless large, considering the number of persons that belong to groups. See L. Dertch \& D. WeInstein, supra note 28, at 104 (over 20 million members of unions and teacher associations).

176. The advantages of clinics may be limited to the provision of routine services for which clinics enjoy a price advantage over traditional firms. See p. 131 supra. For nonroutine services, traditional firms that advertise may be as successful as clinics at increasing lawyer use.

177. See p. 135 supra.

178. High volume may reduce costs by allowing for greater specialization of attorneys, the use of paralegals, employment of systems management involving the standardization and routinization of tasks, and the substitution of cost-saving capital for labor, as in the use of memory typewriters and pre-printed forms. See Muris \& McChesney, supra note 66. Clinics rely on advertising to generate the necessary high volume. Id. at 183 . Closed-panel prepaid plans create high volume by channeling all members' legal problems to a limited number of lawyers. See L. DeIrch \& D. Weinstein, supra note 28, at 74-75; DeMent, supra note 48 , at 630 .

Although the empirical data are limited, they appear to show that closed-panel prepaid plans have costs far lower than those of open panels, see Washingron Conference, supra note 3, at 180 (testimony of Jules Bernstein); Hermann, supra note 56, at 444, and that clinics cost less than traditional firms, see p. 131 supra.

179. However, prepaid plans bear a disadvantage that clinics do not. Nearly $10 \%$ of the sample expressed aversion to the concept of insuring against legal problems. 
similar mechanisms for generating high volume and lower costs. ${ }^{180}$ Our model suggests that of the two cost-saving alternative delivery systems, closed-panel prepaid plans would be more effective than clinics because of their ability to facilitate lawyer contacts. ${ }^{181}$

\section{Conclusion}

Little empirical study has been addressed to the complex processes of lawyer selection and use. This lack of information is complicated further by changing rules governing attorneys' conduct and emerging innovations in the marketing of legal services, including the three major service delivery methods discussed by this Project. Our empirical analysis of the extensive $A B A-A B F$ Survey suggests that experience, property ownership, and personal contacts with lawyers are the most important determinants of lawyer use. The last factor-personal contacts-is relevant in the evaluation of the alternative delivery systems studied. Two service delivery methods-closed-panel prepaid plans and legal clinics-offer the greatest promise for fulfilling the large, unmet public legal need that has long troubled the organized bar. The legal profession should now remove the remaining impediments to their development.

\section{APPENDIX I}

\section{Recoded Data and Computed Variables}

\section{Recoded Variables}

In order to explore and present the data meaningfully, certain variables in the $A B A-A B F$ Survey data were recoded, collapsed from raw form into a smaller number of categories, and redivided so as to separate at significant points. Brief descriptions of variables recoded for the Project follow.

\section{Occupational Status}

Survey respondents were asked their occupations ${ }^{182}$ (Pt. II, Q. 23) and assigned the corresponding Hodge-Siegel occupational prestige score de-

180. Because the LRS refers clients to all panel members, no single panel member can develop a high volume of matters. Open-panel plans may have the potential for generating high volumes by extensively referring clients to a few firms.

181. See p. 152 supra.

182. A copy of the questionnaire is reprinted in B. CURRAN, supra note 7, at 279-382. 
veloped by the National Opinion Research Center (NORC) of the University of Chicago. ${ }^{183}$ The Hodge-Siegel formula combines the normal education, income, and social prestige of various occupations. Then, by rank-ordering occupations according to their association with these traits, it assigns a numerical score to each occupation denoting overall status. The entire Hodge-Siegel scale ranges from 14 to 82 ; the sample had an equally wide range. For cross-tabulation, these scores were stratified into either quartiles or thirds.

\section{Estimated Costs of Attorneys' Services}

In Part $\mathrm{V}$ of the survey, respondents were asked to estimate the cost of a half-hour consultation with a lawyer ( $\mathrm{Pt} . \mathrm{V}, \mathrm{Q} .2 \mathrm{~A}$ ) and of the making of a simple will (Q. 2B). Responses given in dollar amounts were recoded into quartiles for cross-tabulation and occasionally regression. The mean estimate cost for a consultation was $\$ 31$ and for a will, $\$ 85 .{ }^{184}$ There was no observed relationship between respondent income and either the estimated will and consultation costs or willingness to make an estimate -a possible indicator of respondents' awareness of legal fees.

\section{Personal Contact with a Lawyer}

Part V of the survey asked respondents four questions about personal contact with a lawyer. Each was asked if he knew a relative who was a

183. Hodge-Siegel scoring and its ranking of various occupations are discussed in Hodge, Siegel, \& Rossi, Occupational Prestige in the United States 1925-1963, 70 AM. J. Soc. 286 (1964). The efficacy of the Hodge-Siegel index as an indicator of overall sacial status is examined and compared to other status indices in R. Hauser \& D. FeAtherman, The Process of Stratification: Trends and ANalysis 3-59 (1977).

184.

Cost Estimates

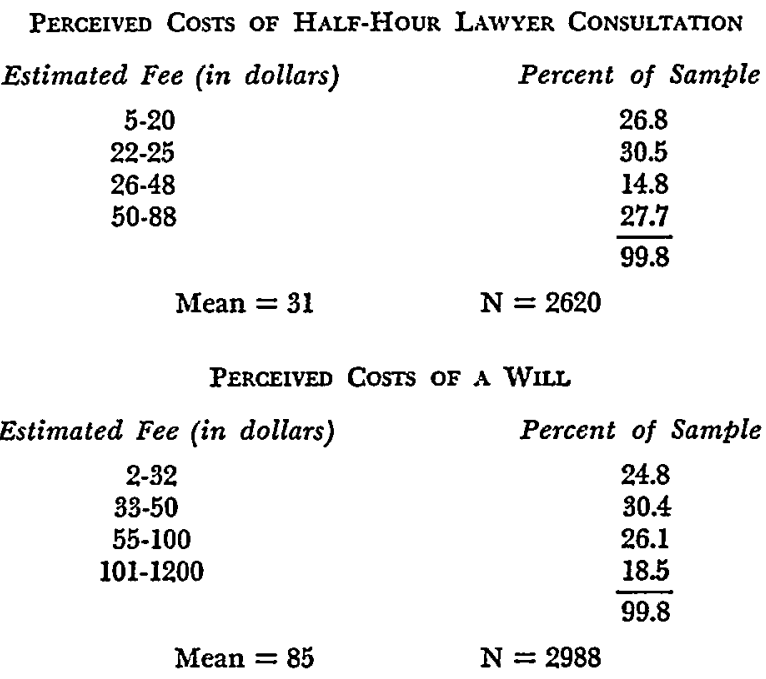




\section{Access to Legal Services}

lawyer (Q. 10); a friend who was a lawyer (Q. 11); a neighbor who was a lawyer (Q. 12); or if he knew a lawyer through some other social context (Q. 13). The Project posited that the exact relationship to a lawyer acquaintance was not as important as the fact of the relationship itself. These various lawyer contacts were recoded so that a respondent received a score of one on a single variable if he indicated knowing a lawyer in any one of the four capacities addressed by the survey. ${ }^{185}$

\section{Computed Variables}

Because much of the raw survey information was fragmented, construction of single variables was often required to measure respondent traits.

185. Frequency distribution of the recoded lawyer contacts variable is compared below with that of its component lawyer contact variables.

CoNTACT WITH LAWYERS (resulting from recoding of four variables)

$$
\begin{array}{lr}
\text { Yes } & 65.2 \\
\text { No } & 34.8 \\
\hline & 100.0
\end{array}
$$

Have a relative who is a lawyer:

\begin{tabular}{lr} 
Yes & 12.3 \\
No & 87.2 \\
No Answer & .5 \\
\cline { 2 - 2 } & 100.0
\end{tabular}

Have a friend who is a lawyer:

\begin{tabular}{lr} 
Yes & 44.6 \\
No & 54.9 \\
No Answer & .6 \\
\hline & 100.1
\end{tabular}

Have a neighbor who is a lawyer:

\begin{tabular}{lr} 
Yes & 22.0 \\
No & 68.1 \\
Don't Know & 9.4 \\
No Answer & .5 \\
\hline & 100.0
\end{tabular}

Have met a lawyer in organizations to which respondent belongs or at work:

\begin{tabular}{lr} 
Yes & 45.0 \\
No & 54.4 \\
No Answer & .6 \\
\cline { 2 - 2 } & 100.0
\end{tabular}

$$
\mathrm{N}=4071
$$




\section{Number of Non-Acute Problems}

The survey identified forty-four situations that give rise to legal problems ${ }^{186}$ and asked respondents if they had encountered such situations. Respondents were also asked how often they had encountered each of the twenty-eight non-acute problems. ${ }^{187} \mathrm{By}$ summing these twenty-eight responses, a variable was constructed to indicate the aggregate number of non-acute problems encountered by each respondent. ${ }^{188}$

\section{Occurrence of Acute Problems}

Because certain situations have more apparent, immediate, and sharp legal consequences than others, a variable composed only of such acute

186. We considered 44 problems deemed in the survey to have legal implications; in contrast, Curran considered only 29 legal problems that frequently befall average citizens. B. Curran, supra note 7, at 103-04. The difference results from the Project having considered each divorce of a respondent to be a separate legal problem, and to its treatment of the following situations-some of which are not intrinsically adversarial-as fraught with potential legal problems: arranging to have a home built ( $Q$. 9); having a house repaired or improved (Q. 11); taking out a mortgage (Q. 13); taking out a loan (Q. 19); garnishment of spouse's wages (Q. 32); going through a bankruptcy ( $Q$. 33); receiving a criminal complaint (Q. 40F); appearing in court as a defendant (for other than criminal charges or traffic violations) (Q.44); appearing in court as a plaintiff (Q. 45); adopting a child (Q. 48); spouse having a will (Q. 57); and group activity to solve a problem (Q. 62). These 12 situations containing legal implication, and the possibility of a second, third, or fourth divorce, result in 15 additional "legal problems" used to compile the Project's list of legal problems but absent from the Curran list.

187. The 28 survey questions (all in Part II of the questionnaire) used in computing the number of non-acute problems variable for this Project were: $7 \mathrm{~A}, 8 \mathrm{~A}, 9 \mathrm{~A}, 10 \mathrm{~A}, 11 \mathrm{~A}$, $12 \mathrm{~A}, 13 \mathrm{~A}, 14 \mathrm{~A}, 16 \mathrm{~A}, 17 \mathrm{~A}, 18 \mathrm{~A}, 19 \mathrm{~A}, 20 \mathrm{~A}, 21 \mathrm{~A}, 25 \mathrm{~A}, 26 \mathrm{~A}, 27 \mathrm{~A}, 28 \mathrm{~A}, 32 \mathrm{~A}, 33 \mathrm{~A}, 38 \mathrm{~A}, 39 \mathrm{~A}$, $45 \mathrm{~A}, 48 \mathrm{~A}, 49 \mathrm{~A}, 50 \mathrm{~A}, 61 \mathrm{~A}$, and $62 \mathrm{~A}$. The Project presented acute problems in a separate computed variable.

188. The following table shows the frequency distribution of this variable.

Number of Non-Acute Problems

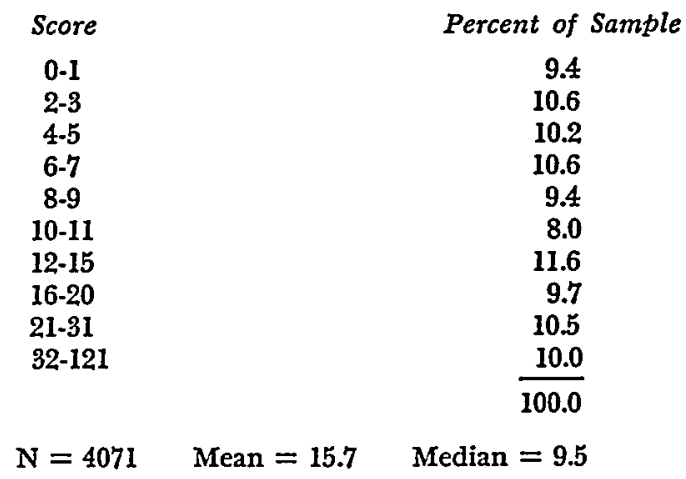

These scores were stratified into deciles for regression and into quartiles for crosstabulation. The Project Code Book (on file with Yale Law Journal) contains complete information about the frequency with which survey respondents encountered these individual problems. 
problems was computed. Situations composing this variable were seeking a divorce (Pt. II, Q. 52) (which recognizes up to four divorces); facing a criminal charge (Pt. II, Q. 41); responding to a criminal complaint made to police in connection with personal injury or property damage (Pt. II, Q. 40F); being named a defendant in a non-criminal, non-traffic case ( $\mathrm{Pt}$. II, Q. 44); and answering a personal injury or property damage claim (Pt. II, Q. 40A). Fifteen percent of the sample experienced at least one of these acute problems.189 For regression, this variable was encoded to range from zero to one. 190

\section{Attitudes Toward Lawyers}

The survey contained twenty-eight questions. Six new attitude variables were constructed from various groupings of the twenty-eight attitude questions. These new variables are presented in Appendix II, infra.

\section{Legal Awareness}

The survey initially presented respondents with six hypothetical situations and then asked what the respondent would do about each. (Pt. I, Qs. 1-6). The responses were encoded with a value of one whenever respondents indicated they would use a lawyer as a resource and a value of zero whenever use of a lawyer was never suggested. A new variable measuring the awareness of the legal implications of the hypothetical problems was then computed by adding together the number of hypothetical problems for which a respondent had suggested use of a lawyer.191

189. The Project Code Book (on file with Yale Law Journal) records the frequency distributions for the component variables constituting the computed acute problems variable.

190. We reasoned that the presence of more acute problems would not make past use of an attorney more likely and that a second acute problem would not be likely to provide greater incentive to seek counsel than the first. The data, which showed the rate of lawser use among respondents with one acute problem to be equivalent to that of respondents with multiple acute problems, confirmed this assumption. The crucial point of demarcation, we concluded, was the occurrence of a first acute problem. We therefore recorded the data so that zero indicated no respondent experience with acute problems and one indicated past respondent experience with one or more acute problems.

191. Suggestion of Lawyer Resource in Response to Hypothetical Legal Problems

$\begin{array}{cr}\text { Times attorney suggested } & \text { Percent of } \\ 0 & 4.1 \\ 1 & 9.9 \\ 2 & 20.3 \\ 3 & 26.4 \\ 4 & 23.0 \\ 5 & 14.6 \\ 6 & 1.6 \\ & \\ & \text { Mean }=3.05\end{array}$

The Project Code Book presents data for each of the six hypothetical problems. 


\section{APPENDIX II}

\section{Variables Derived from Factor Analysis of Attitude Questions}

Part III of the survey contained twenty-eight attitude questions designed to examine respondent attitudes toward lawyers, judges, and the legal system. Respondents were asked to agree or disagree with each of twenty-eight statements about either lawyers or some other aspect of the legal system. Likert Scale scoring defined the range of responses: 1) agree strongly; 2) agree slightly; 3) disagree slightly; 4) disagree strongly; 5) can't decide; 8) don't know; 9) no answer. In order to conduct a factor analysis of the data, question responses were encoded onto a progressive scale, with more favorable responses receiving higher scores. The categories toward lawyers, judges, or the legal system of the resulting code were: I) strongly dislike; 2) dislike; 3) neutral; 4) like; 5) strongly like. ${ }^{102}$

Curran divided the twenty-eight attitude questions of Part III of the survey into seven categories: consulting lawyers, work of lawyers, lawyerclient exchange, cost of lawyers' services, lawyers' ethics, the courts, and the legal system. ${ }^{193}$ This division, although logical to the legally trained onlooker, may not have accurately reflected the actual thought patterns and attitudes of the respondents. Therefore, we chose to apply factor analysis to the attitude-question data, both to seek data parsimony and to discover combinations of responses associated by the survey respondents rather than by onlookers. Factor analysis of the data led to computation of an overall attitude measure-attorall-as well as five distinct attitudinal groupings of question responses represented by variables attlaw, lawsys, judtri, lawethic, and lawwhen.

Factor analysis is a statistical technique that, when applied to a data set, plots the best regression lines that can be constructed for various portions of the data. These plotted lines represent common associations among the data. In effect, they are common threads linking certain variables within the data set. In the technical language, "membership" in these groups is determined by a variable's "loading"-correlation with a given factor. Variables with high loadings on a single factor "belong" in a group, that is, they are associated. ${ }^{194}$ Each of the six attitude variables discussed above is comprised of variables with high loadings on a single one of the six significant factors that could be constructed for the survey's attitude responses. ${ }^{195}$ Use of these newly computed variables provides sev-

192. Space limits preclude a full description of the factoring process resulting in these new measures of respondent attitude. This description is presented in a February 11, 1980, research memorandum by the authors. Factor Analysis of ABA-ABF Survey Attitude Questions (on file with Yale Law Journal).

193. B. CurRan, supra note 7, at 235-36.

194. This explanation of factor analysis is necessarily abbreviated and simplified. For general explanation of factor analysis and the SPSS package's use of this statistical tool, see Kim, Factor Analysis, in N. Nie, C. Hull, J. Jenkins, K. Steinbrenier, \& D. Brent, Statistical Package for the Social Sciences 468 (2d ed. 1975). A more detailed explanation of factor analysis is found in Rummel, Understanding Factor Analysis, II J. Conflict REsotution 444 (1967).

195. The composition of response clusters revealed by factor analysis frequently differed from those imposed on the data in B. CuRRAN, supra note 7. New variables "law" 


\section{Access to Legal Services}

ethic" and "judtri" are substantially similar to Curran's groups "lawyers' ethics" and "the courts." However, factor analysis shows the question response clusters regarding lawyer-client exchange (attlaw), the legal system (lawsys), and consulting lawyers (lawwhen) to be different from those presumed in the $A B A-A B F$ study. Interestingly, no separate factor emerges concerning the cost of lawyers' services. The factor analysis therefore finds an overall measure of attitude and five distinct attitudinal groups of question responses in contrast to the seven groupings discussed by Curran.

The initial construction of the factor matrix through PA2 (principal axes with iteration) factoring produced six factors with an eigenvalue (a numerical characteristic of a matrix) of greater than one. Factors with eigenvalues of less than one are not considered significant explainers of a data mass. See Kim, supra note 194, at 469-78; Rummel, supra note 194, at 462-66. The presence of few significant factors compared to the number of questions and respondents suggests a consistent pattern of responses among the sample. See id. at 463 . These six (unrotated) factors together explain 35.6 percent of the variance in the attitude data. Factor 1 by itself explains 57.3 percent of that part of the variance -that is, 35.6 percent-explained by the six factors. Factor $I$ was also the only one of the first six factors for which many variables possessed high loadings (a minimum of approximately 0.4 correlation between the variable and the factor). For that reason, Factor 1 was used to construct a composite attitude variable, "attorall," composed of the respondent's scores for 13 of the statements.

Questions with similar factor loadings are more closely related than questions with more disparate factor loadings. In essence, each factor resulting from factor analysis represents a common thread in the pattern of responses to the statements. Factors that have many variables loading on (correlating with) them and large eigenvalues are stronger explanatory threads than factors with fewer, lower loadings and smaller eigenvalues. For the largest composite variable, attorall, the common thread was general attitude toward the legal world. However, responses to these 13 statements were more consistent responses than were responses to the full 28 statements.

The 13 questions from Part III of the survey used in computing attorall were Qs. 6, $9,12,13,17,18,19,21,22,24,26,27$, and 28 . The large number of variables loading high on Factor 1 , as well as the many variables having a strong correlation with the factor but not included in the computation of attorall, suggest that each respondent's answers to the Part III questions formed a relatively consistent pattern of attitudes toward the legal world. Graphical plotting of the correlation coefficients between factors confirms this.

Each of the rotated factors that follow represents a distinct subject matter, a more specialized thread common to the response pattern for a smaller number of statements that load high on the rotated factors.

This occurs because the first unrotated factor (the best linear explainer of the data) may be located between independent clusters of associated variables. Rotating the factor matrix removes this potential distortion and "matches" factors with distinct clusters of data. See id. at 473-75. The Project's analysis employed varimax rotation, the most widely used method of orthogonally shifting a factor matrix and the standard rotation method of SPSS. Kim, supra note 194, at 485 .

When the factor matrix is rotated, four distinct clusters of responses emerge. Six variables (Pt. III, Qs. 1, 3, 7, 12, 13, and 14) loaded acceptably high on Rotated Factor 1. These variables are distinguished from the overall attitude variable, attorall, in that all six of these questions deal solely with lawyers as persons rather than lawyers as a part of the legal system. The questions used to compute this new variable, "attlaw," concerned lawyers' trustworthiness; assessment of their own competence; promptness; fairness in figuring fees; frankness and openness with clients; and attention to preventative counseling.

Six variables (Pt. III, Qs. 4, 5, 6, 18, 21, and 22) also load sufficiently high on Rotated Factor 2. This group of questions seems to comprise a cluster of respondent attitudes toward lawyers' conduct within the framework of the legal system rather than toward lawyers" personal qualities. Labeled "lawsys," this variable resulted from questions concerning whether: most people who go to lawyers are troublemakers; the legal system is concerned primarily with problems involving a large amount of money; lawyers adequately understand clients' desires; lawyers care about informing clients; attorneys work harder at getting clients than serving them; lawyers needlessly complicate clients' problems.

Two questions (Pt. III, Qs. 27 and 28) loaded very high on Rotated Factor 3. Actually, 
eral new scales on which to gauge respondents' perceptions of the legal terrain and their effect on behavior. ${ }^{\mathbf{1 9 6}}$

the two questions asked respondents to agree or disagree with the same statement ("Most lawyers would engage in unethical or illegal activities to help a client in an important case."), but Question 27 requested respondents' current opinion whereas Question 28 asked how the respondent would have answered the question a year earlier. The survey, conducted in late 1973 and early 1974, included the second question in an attempt to measure the impact of the Watergate scandal on public attitudes toward lawyers' ethics.

Adding respondent scores on these questions produced a new attitude variable, "lawethic." The clustered variables forming lawethic suggest that the public holds a view of the ethics of attorneys distinct from its view of the entire legal landscape.

A cluster of responses to four questions loading high on Rotated Factor 4 (Pt. III, Qs. 2, 10, 19, and 23) focuses on judges and trials, indicating an overall public attitude toward judges different from its attitudes regarding lawyers, their work, and the system. In these four questions, respondents were asked whether judges: are generally selected from among the most able lawyers; are honest and fair; give adequate time and attention to each case; as well as whether the respondent thought he could receive a fair trial if accused of a crime. This variable, labeled "judtri," resulted from adding response scores to these four questions.

In order to examine carefully the relationships among the attitude questions, a second factor analysis was performed. Those variables loading high on Factor 1 of the initial factor analysis (the questions comprising attorall) were eliminated from this second analysis in order that more subtle relationships in the data might be allowed to emerge. The remaining 15 variables were factored. Three related questions (Pt. III, Qs. 4,5 , and 8 ) possessed high loadings upon a rotated factor in this second analysis. These questions asked whether: people who go to lawyers are troublemakers; the legal system tends to deal primarily with expensive problems; people should not call upon a lawyer until exhausting other ways of dealing with a problem.

It appears that-regardless of their overall attitudes toward law, lawyers, judges, and the legal system-people hold a distinct set of beliefs as to the appropriate circumstances for using a lawyer. Knowing this enables the construction of a variable labeled "lawwhen" to indicate a respondent's relative predisposition to use attorneys. Persons with high lawwhen scores are more inclined to use lawyers when faced with a problem. Respondents with low lawwhen scores are less likely to view consulting a lawyer as apt when faced with the same problem.

196. The following tables show the distribution of scores for each variable (Parentheses following each table contain average score per question used in constructing composite variables.):

Attorall (Overall AtTitude)

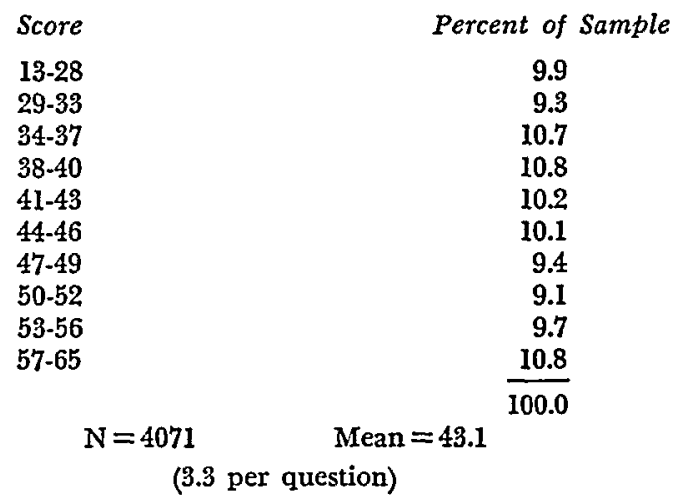


Access to Legal Services

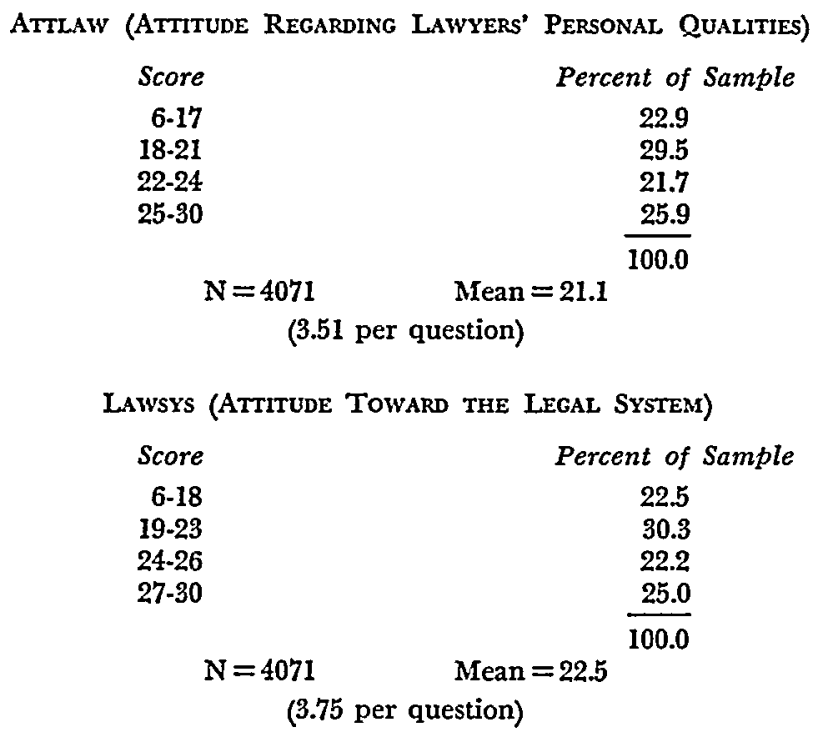

Judtri (Attitude Regarding Judges and Trials)

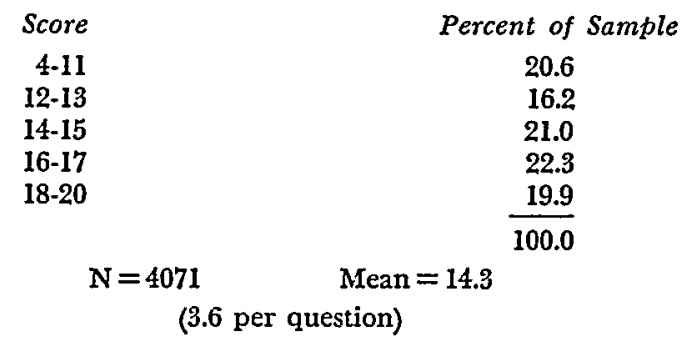

Lawethic (AtTitude About Lawyers' Ethics)

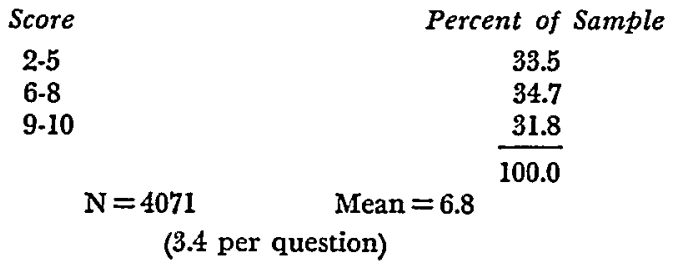

LAwWhen (AtTitude About Using a LAwyer)

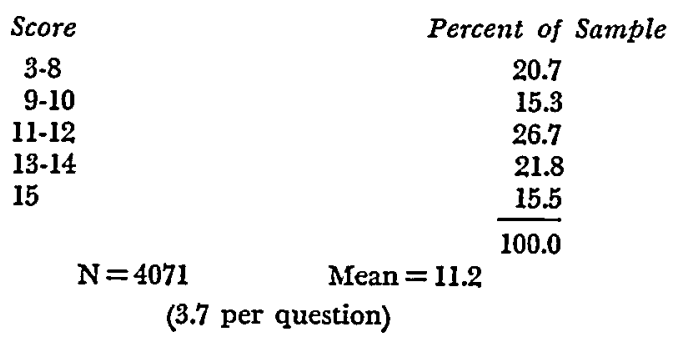




\section{APPENDIX III}

Demographic Profile of Users and Nonusers of Lawyers

Trait

Sex

Race

Age

Number of Non-Acute Problems

Past Presence of an Acute

Problem

Ownership of Real Property .

Income

Hodge-Siegel Occupation Status Score

Personal Direct Contact with a Lawyer

Past Use of Attorney for Own Business ................

Participant in Group that Acted Collectively to Solve Problem

Awareness of Legal Implications Overall Attitude Score ... Lawwhen .............. Attlaw

Lawsys

Cost Estimate of Half-Hour

Consultation .............

Cost Estimate of Simple Will .
Users

$46.6 \%$ male

91.8\% white

46 mean yrs.

$\int 18.5$ mean $\{11.7$ median

$32.1 \%$ of group

$82.4 \%$ of group

$\$ 9,385$ mean $\$ 7,000$ median

40.6 mean

72.3\% of group

$6.2 \%$ of group

$29.7 \%$ of group

3.2 mean

43.4 mean

11.4 mean

21.1 mean

22.7 mean

$\$ 30.49$ mean $\$ 25.19$ median

$\$ 79.47$ mean $\$ 50.20$ median
Nonusers

38.8\% male

87.4\% white

37 mean yrs.

10.2 mean 5.2 median

$11.5 \%$ of group $51.5 \%$ of group $\$ 7,927$ mean $\$ 6,781$ median

36.8 mean $52.3 \%$ of group $1.9 \%$ of group $17.6 \%$ of group 2.9 mean 42.6 mean 11.0 mean 21.0 mean 22.1 mean $\$ 32.92$ mean $\$ 25.36$ median $\$ 96.25$ mean $\$ 50.41$ median 